\title{
The Role of Local Officials in New Democracies: Evidence From Indonesia
}

\author{
Monica Martinez-Bravo \\ Online Appendix
}

\section{Outline of the Online Appendix}

1. Additional Proofs and Discussion on the Theoretical Model ................................... 2

1.1. Graphical Intuition for the Intuitive Criterion .............................................. 2

1.2. Proof of Uniqueness of the Equilibrium satisfying the Divinity Criterion ............. 3

1.3. Additional Discussion about the Assumptions of the model ............................. 7

1.4. Optimal Level of Effort for a General Distribution of the Valence Shock ............ 8

2. Additional Information on Electoral Rules and Political Context ............................. 10

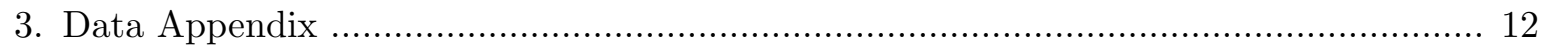

4. Additional Robustness Checks ...................................................................... 13

4.1. Propensity Score Matching: Additional Discussion \& Results ......................... 13

4.2. Endogeneity of the District Level Electoral Result ...................................... 14

4.3. Results on Electoral Violations .................................................................. 16

4.4. Democratic Capital Hypothesis ............................................................. 18

4.5. Robustness to Distance to the Capital of the Subdistrict .................................. 19

4.6. Appointed Village Heads Characteristics across Districts ............................... 21

4.7. Multinomial Choice Models ......................................................................... 21

4.8. Robustness of Turnover Results ............................................................. 23

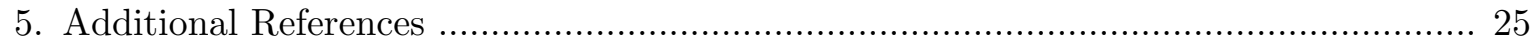

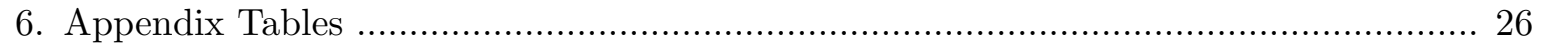

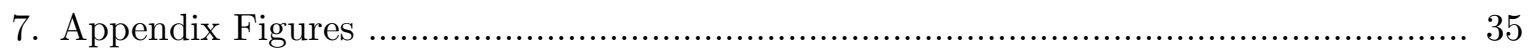




\section{Additional Proofs and Discussion on the Theoretical Model}

\subsection{Graphical Intuition for the Intuitive Criterion}

In the proof of Proposition 2 of the Mathematical Appendix, I provided a formal proof that the pooling PBE with effort level $e^{*}$ satisfies the Intuitive Criterion. In this online appendix I provide a graphic illustration of that proof. Figure A.2. shows the deviation payoffs of both types of appointed village heads as a function of the deviation effort. In particular, it shows the deviation payoffs for two different out of equilibrium beliefs: the left hand side panel shows the deviation payoffs when out of equilibrium beliefs are $\mu\left(t=d \mid e \neq e^{*}\right)=0$, while the right hand side panel displays the deviation payoffs when out of equilibrium beliefs are $\mu\left(t=d \mid e \neq e^{*}\right)=1$. The graph also shows the level of equilibrium payoffs $U^{*}(t=d)$ and $U^{*}(t=r)$.

As we can see, type $d$ obtains a higher payoff in equilibrium than what he would achieve undertaking any possible deviation, for either out of equilibrium beliefs. On the contrary, type $r$ could conceivably increase his payoffs by deviating to $e^{*}-\varepsilon$, for $\varepsilon>0$ and small, conditional on out of equilibrium beliefs being $\mu\left(t=d \mid e \neq e^{*}\right)=1$. However, since type $d$ would never have deviated to $e^{*}-\varepsilon$, mayors would deduce the deviator is type $r$. Hence, the relevant deviation payoffs would be those on the left hand side of the graph and, consequently, deviation $e^{*}-\varepsilon$ would not be profitable for type $r$.

A similar figure is useful to illustrate the set of pooling PBE, and the subset of those that satisfy the Intuitive Criterion. In the right hand side of Figure A.3, I plot the equilibrium payoffs of appointed village head for strategies and beliefs given by (9) as a function of the equilibrium level of effort. In the left hand side I plot the deviation payoffs. ${ }^{1}$ Then, it is straightforward to see that the equilibrium levels of effort $e \in\left[e_{1}, e_{3}\right]$ constitute $\mathrm{PBE}$ of this game, since type $r$ does not have incentives to deviate. Notice also that effort levels $e \in\left[e_{2}, e^{*}\right)$ are PBE, but do not satisfy the Intuitive Criterion: for every $\widehat{e} \in\left[e_{2}, e^{*}\right)$ that constitutes a PBE, type $d$ could deviate to $\widehat{e}+\varepsilon$ and send a speech to mayors claiming to be type $d$. This speech would be credible since type $r$ would have never deviated to $\widehat{e}+\varepsilon$. In contrast, effort levels $e \in\left[e_{1}, e_{2}\right) \cup\left(e^{*}, e_{3}\right]$ are associated to $\mathrm{PBE}$ that $d o$ satisfy the Intuitive Criterion: since both types could potentially benefit from some deviations, none of them can reveal their type by deviating and sending a speech. In the next subsection, I provide a formal proof that these PBE do not satisfy the Divinity Criterion.

\footnotetext{
${ }^{1}$ This figure is only intended for illustration purposes. Notice that deviation payoffs depend on the total level of effort exerted in equilibrium. Hence, deviation payoffs of different equilibria cannot be represented by the same function: an equilibrium with higher aggregate effort will have a deviation payoff shifted downwards. However, as long as $\theta$ is low, Figure A.3. provides a good approximation
} 


\subsection{Proof of Uniqueness of the Equilibrium satisfying the Divinity Criterion}

In order to define the Divinity Criterion I introduce some additional notation. Let $M B R_{D}(T, e)$ be the set of mixed strategy best responses of candidate for mayor $D$ given beliefs $\mu(. \mid e)$ such that $\mu(T \mid e)=1$, that is, $M B R_{D}(T, e)=\underset{\mu: \mu(T \mid e)=1}{\cup} M B R_{D}(\mu \mid e) . M B R_{R}(T, e)$ is defined similarly.

Fix a particular equilibrium with vector of equilibrium payoffs $U^{*}($.$) . Consider a given out of$ equilibrium effort, $e$, and type, $t$. Denote by $q_{D}, q_{R}$ mixed strategies played by mayor $D$ and $R$, respectively. ${ }^{2}$ Let $D(t, T, e)$ be the set of mixed strategies of mayors that are best responses to deviation $e$ for beliefs, that are concentrated in the subset of types $T \subseteq \Theta$, and that make type $t$ strictly prefer $e$ to his equilibrium strategy.

$$
D(t, T, e)=\underset{\mu: \mu(T \mid e)=1}{\cup}\left\{\begin{array}{c}
q_{D} \in M B R_{D}(T, e), q_{R} \in M B R_{R}(T, e) \text { s.t. } \\
U^{*}(t)<p\left(E_{-i}+e\right) U_{t}^{a p p}\left(e, q_{D}\right)+\left(1-p\left(E_{-i}+e\right)\right) U_{t}^{a p p}\left(e, q_{R}\right)
\end{array}\right\}
$$

Let $D^{0}(t, T, e)$ be defined similarly as the set of mixed strategies of mayors that make type $t$ exactly indifferent between deviation to $e$ and following the equilibrium actions.

Definition 3. The Divinity Criterion. If for some type $t$ there exists a second type $t^{\prime}$ with

$$
D(t, T, e) \cup D^{0}(t, T, e) \subseteq D\left(t^{\prime}, T, e\right)
$$

then, $(t, e)$ may be pruned from the game.

The intuition for this criterion is the following: if the criterion holds, it means that type $t^{\prime}$ strictly wishes to defect whenever type $t$ is indifferent between defection and following the equilibrium actions. This leads mayors to believe that it is infinitely more likely that defection to $e$ was undertaken by type $t^{\prime}$ than by type $t$. Once the pair $(t, e)$ is pruned from the game, I revise the out of equilibrium beliefs and best responses of mayors. Then, I evaluate if the equilibrium actions can still be sustained. By following this procedure, I next show that PBE with associated levels of effort $\widetilde{e} \in\left[e_{1}, e_{2}\right) \cup\left(e^{*}, e_{3}\right]$ do not satisfy the Divinity Criterion.

Claim 2. Consider a pooling PBE as defined by (9) with equilibrium level of effort $\widetilde{e} \in\left[e_{1}, e_{2}\right)$ and deviation $e^{\prime}=\widetilde{e}+\varepsilon$ ( $\varepsilon$ positive and small). Then, $D\left(t=r, \Theta, e^{\prime}\right) \cup D^{0}\left(t=r, \Theta, e^{\prime}\right) \subseteq D(t=$ $\left.d, \Theta, e^{\prime}\right)$.

Proof. First, notice that the equilibrium payoff of each type are:

$$
\begin{aligned}
& U_{d}^{*}(\widetilde{e})=p(n \widetilde{e})(Z-\underline{U})+\underline{U}-\underline{\alpha} C(\widetilde{e}) \\
& U_{r}^{*}(\widetilde{e})=p(n \widetilde{e})(Z-\underline{U})+\underline{U}-\bar{\alpha} C(\widetilde{e})
\end{aligned}
$$

In order to prove Claim 2, I first find the set of mixed strategy best responses that make type $r$ strictly better off deviating to $e^{\prime}$ than following the equilibrium actions - i.e., $D\left(t=r, \Theta, e^{\prime}\right)$. Note

\footnotetext{
${ }^{2} q_{D}$ is the probability of choosing $\phi_{D}=1$ in a mixed strategy of mayor $D$. Similarly for $q_{R}$.
} 
that this set contains mixed strategies that can be sustained for any out of equilibrium beliefs. Let me first focus on the set of parameters such that $\frac{G-\kappa}{G}>\frac{1}{2}$. I will discuss the case in which $\frac{G-\kappa}{G} \leq \frac{1}{2}$ at the end of this proposition.

i. $\mu(t=d \mid e \neq \widetilde{e})=1$ or $\mu(t=d \mid e \neq \widetilde{e})=\theta$, where $\theta>\frac{G-\kappa}{G}>1-\theta$. In these two cases, the best responses of mayors are to play pure strategies $\phi_{D}=1$ and $\phi_{R}=0$. This leads to deviation payoffs $U_{r}\left(e^{\prime}=\widetilde{e}+\varepsilon\right)=p(n \widetilde{e}+\varepsilon)(Z-\underline{U})+\underline{U}-\bar{\alpha} C(\widetilde{e}+\varepsilon)$, which are higher than the equilibrium payoff since $\widetilde{e} \in\left[e_{1}, e_{2}\right)$ (see Figure A.3). Hence, $\left\{q_{D}=1, q_{R}=0\right\} \in D\left(t=r, \Theta, e^{\prime}\right)$.

ii. $\mu(t=d \mid e \neq \widetilde{e})=0, \mu(t=d \mid e \neq \widetilde{e})=\theta$, where $1-\theta>\frac{G-\kappa}{G}>\theta$, or $\frac{G-\kappa}{G}>\theta$ and $\frac{G-\kappa}{G}>1-\theta$. In these two cases, the best responses of mayors are to play pure strategies $\phi_{D}=0$ and $\phi_{R}=1$. In these cases the deviation payoffs are lower than the equilibrium payoffs and, therefore, these strategies do not belong in the set $D\left(t=r, \Theta, e^{\prime}\right)$.

iii. $\mu(t=d \mid e \neq \widetilde{e})=\theta$, where $\theta=\frac{G-\kappa}{G}>1-\theta$. In this case, mayor $R$ plays pure strategy $\phi_{R}=0$. Mayor $D$ is indifferent between pure strategy actions $\phi_{D}=1$ and $\phi_{D}=0$. Mayor $D$ plays a mixed strategy with $q_{D}$ representing the probability of action $\phi_{D}=1$. Type $r$ 's deviation payoffs are strictly higher than equilibrium payoffs as long as $q_{D} \in\left(q_{D \bar{\alpha}}, 1\right]$ where $^{3}$

$$
q_{D \bar{\alpha}}=\frac{\bar{\alpha}[C(\widetilde{e}+\varepsilon)-C(\widetilde{e})]+p(n \widetilde{e})(Z-\underline{U})}{p(n \widetilde{e}+\varepsilon)(Z-\underline{U})}
$$

Hence, $\left\{q_{D} \in\left(q_{D \bar{\alpha}}, 1\right], q_{R}=0\right\} \in D\left(t=r, \Theta, e^{\prime}\right)$. Notice that type $r$ is exactly indifferent between deviating or not deviating if $q_{D}=q_{D \bar{\alpha}}$ and $q_{R}=0$.

iv. $\mu(t=d \mid e \neq \widetilde{e})=\theta$, where $\theta>\frac{G-\kappa}{G}=1-\theta$. In this case, mayor $D$ plays pure strategy $q_{D}=1$. Mayor $R$ plays mixed strategy $q_{R}$. Type $r$ 's deviation payoffs are strictly higher than equilibrium payoffs as long as $q_{R} \in\left(q_{R \bar{\alpha}}, 1\right]$ where

$$
q_{R \bar{\alpha}}=\frac{\bar{\alpha}[C(\widetilde{e}+\varepsilon)-C(\widetilde{e})]+[p(n \widetilde{e})-p(n \widetilde{e}+\varepsilon)](Z-\underline{U})}{[1-p(n \widetilde{e}+\varepsilon)](Z-\underline{U})}
$$

Hence, $\left\{q_{D}=1, q_{R} \in\left(q_{R \bar{\alpha}}, 1\right]\right\} \in D\left(t=r, \Theta, e^{\prime}\right)$.

v. $\mu(t=d \mid e \neq \widetilde{e})=\theta$, where $1-\theta=\frac{G-\kappa}{G}>\theta$. In this case, mayor $D$ plays pure strategy $q_{D}=0$. Mayor $R$ plays a mixed strategy $q_{R}$. However, notice that this leads to a deviation payoff lower than in case $i i$. Hence, these strategies are not part of the set $D\left(t=r, \Theta, e^{\prime}\right)$.

vi. $\mu(t=d \mid e \neq \widetilde{e})=\theta$ where $1-\theta>\frac{G-\kappa}{G}=\theta$. In this case, mayor $R$ plays pure strategy $q_{R}=1$. Mayor $D$ plays a mixed strategy $q_{D}$. Type $r$ 's deviation payoffs are strictly higher than equilibrium payoffs as long as $q_{D} \in\left(\widehat{q}_{D \bar{\alpha}}, 1\right]$ where

$$
\widehat{q}_{D \bar{\alpha}}=\frac{\bar{\alpha}[C(\widetilde{e}+\varepsilon)-C(\widetilde{e})]+[p(n \widetilde{e})-p(n \widetilde{e}+\varepsilon)-1](Z-\underline{U})}{p(n \widetilde{e}+\varepsilon)(Z-\underline{U})}
$$

\footnotetext{
${ }^{3} q_{D \bar{\alpha}}$ is obtained by equating the deviation payoffs of type $r$ to his equilibrium payoffs, i.e., $[1-p(n \widetilde{e}+\varepsilon)] \underline{U}+$ $p(n \widetilde{e}+\varepsilon) q_{D \bar{\alpha}} Z+p(n \widetilde{e}+\varepsilon)\left(1-q_{D \bar{\alpha}}\right) \underline{U}=U_{r}^{*}(\widetilde{e})$
} 
Hence, $\left\{q_{D} \in\left(\widehat{q}_{D \bar{\alpha}}, 1\right], q_{R}=1\right\} \in D\left(t=r, \Theta, e^{\prime}\right)$.

vii. $\mu(t=d \mid e \neq \widetilde{e})=\theta$ where $\theta \geq \frac{G-\kappa}{G}$ and $1-\theta \geq \frac{G-\kappa}{G}$. This case is ruled out by the restriction to the set of parameters that satisfy $\frac{G-\kappa}{G} \leq \frac{1}{2}$.

Notice that type $r$ is exactly indifferent between deviating and not deviating when the corresponding mixing probabilities are equal to $q_{D \bar{\alpha}}, q_{R \bar{\alpha}}$, and $\widehat{q}_{D \bar{\alpha}}$. Hence, I have shown that if $\frac{G-\kappa}{G} \leq \frac{1}{2}$ :

$$
D\left(t=r, \Theta, e^{\prime}\right) \cup D^{0}\left(t=r, \Theta, e^{\prime}\right)=\left\{\begin{array}{c}
\left\{q_{D}=1, q_{R}=0\right\},\left\{q_{D} \in\left[q_{D \bar{\alpha}}, 1\right], q_{R}=0\right\}, \\
\left\{q_{D}=1, q_{R} \in\left[q_{R \bar{\alpha}}, 1\right]\right\},\left\{q_{D} \in\left[\widehat{q}_{D \bar{\alpha}}, 1\right], q_{R}=1\right\}
\end{array}\right\}
$$

In order to complete the proof of Claim 2, I need to find $D\left(t=d, \Theta, e^{\prime}\right)$. Notice that, for any possible out of equilibrium beliefs, the deviation payoff of type $d$ is the same as type $r$, except for the value of the parameter $\alpha .{ }^{4}$ Hence, the set of mixed strategies that make type $d$ strictly better off by deviating are $\left\{q_{D} \in\left(q_{D \underline{\alpha}}, 1\right], q_{R}=0\right\}$ where $q_{D \underline{\alpha}}<q_{D \bar{\alpha}} .{ }^{5}$ The same applies for the other cases in which mixed strategies are played.

Therefore we have:

$$
D\left(t=d, \Theta, e^{\prime}\right)=\left\{\begin{array}{c}
\left\{q_{D}=1, q_{R}=0\right\},\left\{q_{D} \in\left(q_{D \underline{\alpha}}, 1\right], q_{R}=0\right\} \\
\left\{q_{D}=1, q_{R} \in\left(q_{R \underline{\alpha}}, 1\right]\right\},\left\{q_{D} \in\left(\widehat{q}_{D \underline{\alpha}}, 1\right], q_{R}=1\right\}
\end{array}\right\}
$$

where $q_{D \underline{\alpha}}<q_{D \bar{\alpha}}, q_{R \underline{\alpha}}<q_{R \bar{\alpha}}$, and $\widehat{q}_{D \underline{\alpha}}<\widehat{q}_{D \bar{\alpha}}$. Consequently I have shown that for $\frac{G-\kappa}{G} \leq \frac{1}{2}$, $D\left(t=r, \Theta, e^{\prime}\right) \cup D^{0}\left(t=r, \Theta, e^{\prime}\right) \subseteq D\left(t=d, \Theta, e^{\prime}\right)$ holds. This concludes the proof of Claim 2.

According to the divinity criterion the pair $\left(t=r, e^{\prime}\right)$ can be pruned from the game. This means that, upon observing a deviation to $e^{\prime}=\widetilde{e}+\varepsilon$, mayors deduce the type that deviates is type $t=d$, and update their out of equilibrium beliefs accordingly. However, given this revision of beliefs, type $d$ has an incentive to deviate to $e^{\prime}$. We can observe this in Figure A.3. For $\widetilde{e} \in\left[e_{1}, e_{2}\right) \cup\left(e^{*}, e_{3}\right]$, type $d$ will have a higher payoff by deviating to $\widetilde{e}+\varepsilon$. Consequently, I can say that the pooling PBE $\widetilde{e}$ does not satisfy the divinity criterion.

The same argument can be applied to any pooling PBE that $\widetilde{e} \in\left[e_{1}, e_{2}\right) \cup\left(e^{*}, e_{3}\right]$ : all of those pooling PBE fail to satisfy the divinity criterion. ${ }^{6}$ Intuitively, in any of these PBE, type $d$ is more likely to deviate than is type $r$ : a larger set of best responses mixed-strategies of mayors would make a deviation profitable for type $d$.

\footnotetext{
${ }^{4}$ For instance, for out of equilbrium believes $\mu(t=d \mid e \neq \widetilde{e})=\theta$ where $\theta=\frac{G-\kappa}{G}>1-\theta$ (case $\left.i i i\right)$ the deviation payoff of the two types is given by:

$$
\begin{aligned}
& U_{r}\left(e^{\prime}=\widetilde{e}+\varepsilon\right)=[1-p(n \widetilde{e}+\varepsilon)] \underline{U}+p(n \widetilde{e}+\varepsilon) q_{D} Z+p(n \widetilde{e}+\varepsilon)\left(1-q_{D}\right) \underline{U}-\bar{\alpha} C(\widetilde{e}+\varepsilon) \\
& U_{d}\left(e^{\prime}=\widetilde{e}+\varepsilon\right)=[1-p(n \widetilde{e}+\varepsilon)] \underline{U}+p(n \widetilde{e}+\varepsilon) q_{D} Z+p(n \widetilde{e}+\varepsilon)\left(1-q_{D}\right) \underline{U}-\underline{\alpha} C(\widetilde{e}+\varepsilon)
\end{aligned}
$$

${ }^{5} q_{D \underline{\alpha}}$ is defined similarly as (2) except for parameter $\underline{\alpha}$, which is replaced by $\bar{\alpha}$.

${ }^{6}$ The proof for the other cases, in particular $\widetilde{e} \in\left(e^{*}, e_{3}\right]$, is very similar to the one above and it is omitted for the sake of brevity.
} 
Finally, what remains to be proven is that the pooling PBE with equilibrium level of effort $e^{*}$ does satisfy the Divinity Criterion, where $e^{*}$ is defined by

$$
\frac{\psi \theta[Z-\underline{U}]}{\underline{\alpha}}=C^{\prime}\left(e^{*}\right)
$$

In order to show this, I first prove the following claim.

Claim 3. Consider the pooling PBE as defined by (9) with equilibrium level of effort $e^{*}$ as defined by (5). If $\frac{G-\kappa}{G}>\frac{1}{2}$, then $D\left(t=d, \Theta, e^{\prime}\right)=\{\varnothing\}$ for any $e^{\prime}$.

Proof. The level of effort $e^{*}$ is defined so that type $d$ does not have a profitable deviation, even when out of equilibrium beliefs are $\mu\left(t=d \mid e \neq e^{*}\right)=1$. Hence if $\frac{G-\kappa}{G}>\frac{1}{2}$, there are no best response of mayors that could make type $d$ better off after a deviation. It is straightforward to verify this for each subcase $i-v i$ discussed above.

Therefore, as long as $\frac{G-\kappa}{G}>\frac{1}{2}$, the condition $D(t=r, T, e) \cup D^{0}(t=r, T, e) \subseteq D(t=d, T, e)$ is not satisfied and the PBE with level of effort $e^{*}$ satisfies the Divinity Criterion. The intuition is similar to the one provided for the Intuitive Criterion. Since type $d$ is obtaining his maximum possible payoff, he cannot reveal his type by deviating. On the contrary, type $r$ could potentially reveal his type by deviating to some negative level of effort. However, it is not in his interest to do so. ${ }^{7}$

Finally, I discuss the situation in which $\frac{G-\kappa}{G} \leq \frac{1}{2}$ holds. For this set of parameters there can be out of equilibrium beliefs such that $\mu(t=d \mid e \neq \widetilde{e})=\theta$ where $\theta \geq \frac{G-\kappa}{G}$ and $1-\theta \geq \frac{G-\kappa}{G}$. This means that the following best responses of mayors can be sustained: $\phi_{D}=1$ and $\phi_{R}=1$, one of them playing a mixed strategy and the other playing $\phi_{m}=1$, or both playing mixed strategies. In the case in which mayors play $\phi_{D}=1$ and $\phi_{R}=1$, the deviation payoffs for type $d$ are $U_{d}\left(e^{\prime}\right)=Z-\underline{\alpha} C\left(e^{\prime}\right)$, which are higher than the payoffs in any PBE described by (9). As a result, the following holds $D\left(t=r, \Theta, e^{\prime}\right) \cup D^{0}\left(t=r, \Theta, e^{\prime}\right) \subseteq D\left(t=d, \Theta, e^{\prime}\right)$. That is, in any pooling $\mathrm{PBE}$, including the equilibrium in which effort is $e^{*}$, type $d$ strictly wants to deviate when type $r$ is indifferent. Hence, type $d$ could potentially reveal his type by undertaking a particular deviation. However, if and only if the pooling PBE considered is $e^{*}$, it is not in type $d$ 's interest to undertake such deviation. Remember that upon revealing d's type, the updated mayors' beliefs will be $\mu(t=d \mid e \neq \widetilde{e})=1$. When the pooling PBE considered has effort level $e^{*}$, by construction the resulting deviation payoffs are lower than the equilibrium payoffs of type $d$. Hence, I conclude that regardless of the value of $\frac{G-\kappa}{G}$, the pooling PBE with equilibrium effort level $e^{*}$ is the only equilibrium that satisfies the Divinity Criterion. This completes the proof of Proposition 2.

\footnotetext{
${ }^{7} \mathrm{I}$ do not provide a formal proof of the latter statement. It can be shown that for deviations to negative levels of effort $e^{\prime \prime}$, the following holds: $D\left(t=d, T, e^{\prime \prime}\right) \cup D^{0}\left(t=d, T, e^{\prime \prime}\right) \subseteq D\left(t=r, T, e^{\prime \prime}\right)$. However, pruning from the equilibrium the pair $\left(t=d, e^{\prime \prime}\right)$ does not eliminate the PBE considered because it is not in the interest of type $r$ to undertake deviation $e^{\prime \prime}$, even with the corresponding update of mayors' beliefs.
} 


\subsection{Additional Discussion about the Assumptions of the Model}

In this subsection I provide some additional discussion on the assumptions made in the theoretical analysis and the extent to which these assumptions can be relaxed.

Asymmetric Information of Political Leanings of Elected Village Heads. The model assumes that the political sympathies of village heads are private information. However, notice that the results of the model are robust to relaxing the information assumption about the political leanings of elected village heads. This is so because it would still be optimal for elected village heads to exert zero effort, even though their political sympathies were known. Nevertheless, the model requires that the political leanings of appointed village heads are private information, which is a more plausible assumption given that they had strong incentives to pretending to be dictator supporters during the non-democratic period.

Availability of True Supporters in the Democratic Period. In the model, I assume that upon the dismissal of an appointed village head the mayor can appoint one of her cronies that she knows for sure is aligned with her. Hence, I assume that, in the democratic period, each party has a group of strong supporters who are committed to the party, and there is no uncertainty about their political leanings. In contrast, during the nondemocratic regime, anyone who wanted to be a village head had to pretend to share the same ideology as the dictator. The results of the model still hold if the technology to identify supporters is only slightly better during the democratic period than during the nondemocratic regime, which is a plausible assumption.

Effect of Village Heads' Effort on Vote Shares. The model assumes that the aggregate levels of effort exerted by village heads affects the vote shares of district mayors in a linear fashion. In particular, I assume that $g(E)=\theta E$. The linear assumption is chosen for analytical simplicity. The model is generalizable to allow any function twice continuously differentiable function $g($.$) that$

satisfies $g(0)=0, \frac{\partial g(E)}{\partial E} \geq 0, \frac{\partial^{2} g(E)}{\partial E^{2}} \leq 0$ if $E>0$ and $\frac{\partial^{2} g(E)}{\partial E^{2}} \geq 0$ if $E<0$. The derivations are available from the author upon request.

Lack of Commitment. Notice that given the timing of events specified in the model, mayors cannot commit to implementing any strategy different from their optimal one upon being elected. Otherwise, they could find it optimal to offer a more sophisticated contract to village heads during the electoral campaign, in order to give them incentives to exert effort. However, once elected, mayors have no incentive to fulfill their promises. This is why the preferences of mayors that are relevant are those at an interim stage, that is, those preferences that mayors have immediately after being elected.

Checking Individual Deviations. Notice that, in equilibrium, all village heads of a particular type exert the same level of effort. This result is derived from the symmetry of their optimization problems and it is common to all equilibria described in this paper. In order to minimize notation, often I omit the $i$ subscript. However, when checking for deviations from the equilibrium path, I 
consider the deviation of a single individual of a particular type, holding constant the actions of any other village head of either type.

\subsection{Optimal Level of Effort for a General Distribution of the Valence Shock}

Consider the model presented in Section 2 introducing the following modification:

New Assumption: valence shock $\varphi$ is distributed according to the cumulative distribution function $F(\varphi)$, with corresponding probability distribution function $f(\varphi)$, which is a unimodal function, with mode at $\varphi=0$, and symmetric around at 0 . For instance, $\varphi$ could follow a Standard Normal distribution.

The realized vote share of party $D$ is defined according to the following function

$$
\widehat{\pi}=\pi+\varphi+g(E)
$$

Following the specification of in the paper we assume that $g(E)=\theta E$. Given this and the distribution of the valence shock, we obtain the following expression of the probability that party $D$ wins the election:

$$
p(E)=\underset{\varphi}{\operatorname{Prob}}\left[\pi+\theta E+\varphi \geq \frac{1}{2}\right]=1-F\left(\frac{1}{2}-\pi-\theta E\right)=F\left(\pi+\theta E-\frac{1}{2}\right)
$$

\section{Pooling Equilibrium towards party $D$}

The level of effort that satisfies the Intuitive Criterion in the pooling equilibrium towards party $D$, is now defined by.

$$
\begin{aligned}
e^{*}= & \underset{e}{\arg \max }\left\{p\left((n-1) e^{*}+e\right)(Z-\underline{U})-\underline{\alpha} C(e)\right\} \\
e^{*}= & \underset{e}{\arg \max }\left\{F\left(\pi+\theta\left((n-1) e^{*}+e\right)-\frac{1}{2}\right)(Z-\underline{U})-\underline{\alpha} C(e)\right\} \\
& f\left(\pi+\theta\left((n-1) e^{*}+e\right)-\frac{1}{2}\right) \theta(Z-\underline{U})=\underline{\alpha} C^{\prime}(e)
\end{aligned}
$$

where $f($.$) is the probability distribution function of the valence shock \varphi .^{8}$ Imposing the equilibrium condition $e=e^{*}$ this equation becomes:

$$
f\left(\pi+\theta n e^{*}-\frac{1}{2}\right) \theta(Z-\underline{U})=\underline{\alpha} C^{\prime}\left(e^{*}\right)
$$

\footnotetext{
${ }^{8}$ Notice that it is straightforward to show that equation (10) uniquely defines an equilibrium level of effort. The right hand side of equation (10) is increasing due to the convexity of the cost function; while the left hand side is decreasing as long as $\pi+\theta\left((n-1) e^{*}+e\right)>\frac{1}{2}$ which has to hold for the pooling equilibrium towards party $D$ to exist.
} 
Notice that the level of effort $e^{*}$ implicitly defined by (11) is now a function of the $\pi$, the underlying strength of party $D$ among the population. In particular, using the implicit function theorem is straightforward to show that more close elections leads to higher equilibrium levels of effort.

Let us define

$$
G\left(\pi, e^{*}\right)=f\left(\pi+\theta n e^{*}-\frac{1}{2}\right) \theta(Z-\underline{U})-\underline{\alpha} C^{\prime}\left(e^{*}\right)
$$

By the implicit function theorem we know that

$$
\frac{d e^{*}}{d \pi}=\frac{\frac{-\partial G}{\partial \pi}}{\frac{\partial G}{\partial e^{*}}}=\frac{\left.\frac{-\partial f}{\partial \pi}\right|_{\pi+\theta n e^{*}-\frac{1}{2}}}{\left.\frac{\partial f}{\partial e^{*}}\right|_{\pi+\theta n e^{*}-\frac{1}{2}}-C^{\prime \prime}(e)}
$$

As long as $\pi+\theta n e^{*}-\frac{1}{2}>0$, the numerator of the above expression is positive, while the denominator is negative. Hence, we have that $\frac{d e^{*}}{d \pi}<0$.

The intuition for this result is the following: when the most likely valence shock has a neutral effect (i.e., the mode of the unimodal distribution is $\varphi=0$ ), the closer is an election, the more likely it is that a given level of effort makes the realized vote share cross the $1 / 2$ threshold. This higher marginal effect of effort on the probability of victory leads to equilibrium effort being higher in close elections.

The main drawback of assuming a unimodal distribution of the valence shock is that the model and its presentation becomes considerably more cumbersome: the model requires a heavier use of notation and the derivations of the conditions under which the PBE exist no longer have closed form solutions. This is the main reason why the uniform distribution is so extensively used in probabilistic voting models and why the version of the model presented in the paper uses the uniform distribution. Additional derivations using a unimodal distribution for the valence shock are available from the author upon request.

\section{Separating Equilibrium}

Similarly, the conditions that guarantee the existence of a separating PBE also become cumbersome. Here I provide a summary of the analysis. Consider the following set of strategies and beliefs

$$
\begin{aligned}
& \phi_{D}^{*}(e)= \begin{cases}1 \text { if } e \geq 0 & e_{i}^{*}(t=d)=e_{s}^{*} \\
0 \text { if } e<0 & e_{i}^{*}(t=r)=-e_{s}^{*}\end{cases} \\
& \phi_{R}^{*}(e)=\left\{\begin{array}{l}
0 \text { if } e \geq 0 \\
1 \text { if } e<0
\end{array}\right. \\
& \mu(t=d \mid e)=\left\{\begin{array}{l}
1 \text { if } e \geq 0 \\
0 \text { if } e<0
\end{array}\right.
\end{aligned}
$$


where $e_{s}^{*}$ is implicitly defined by

$$
f\left(\pi+\theta(2 \delta-1) n e_{s}^{*}-\frac{1}{2}\right) \theta(Z-\underline{U})=\underline{\alpha} C^{\prime}\left(e_{s}^{*}\right)
$$

Notice that $e_{s}^{*}$ is also a function of $\pi$. In particular the equilibrium level of effort is higher, the closer is the election.

\section{Additional Information on Electoral Rules and Political Context}

\section{Electoral Rules}

As mentioned in the text in the 1999 elections the electorate voted simultaneously for the national, provincial, and district legislatures.

The district level legislative elections were single-district multiple seat elections. The Law Number 3 of year 1999 stipulated that the apportionment of seats to political parties had to be proportional to the number of votes obtained in the district (Article 67). Additional regulation promulgated by the electoral commission (KPU) provided more detailed instruction for the allocation of seats to parties. In particular the system used was the method of full quota and largest reminders. The total number of votes is divided by the number of seats +1 . The resulting number is the quota. Then the seats are assigned to parties that obtained more votes than the quotas. After this first step, the unassigned seats are assigned sequentially to the party with the highest remainder - i.e, the number of votes a party obtained minus the number of votes used in fulfilling the quotas.

A number of regulations on party registration contained in the electoral law, Number 3 of year 1999, ensured that only national level parties were allowed to contest the elections. In order to be eligible to participate in the 1999 election, parties had to have substantial representation all over the country. This regulation was introduced in order to avoid the emergence of regional parties that would run on separatist platforms. In particular, parties had to provide evidence that they had a committee in more than half of the provinces of Indonesia. In those provinces, they had to have a committee in one third of the districts. (Law Number 3 of year 1999, article 39). This regulation de facto prevented regional parties from contesting the election (Sherlock 2004). As a result, the set of parties contesting the district-level elections was the same in all districts of Indonesia.

The newly constituted legislatures, in turn, elected the head of the executive branch of the corresponding level of government. The selection of district mayors was staggered across time because the incumbent district mayor was allowed to finish their 5 year term. This generated exogenous variation in timing of the election of the new district mayor as documented by Skoufias et. al. (2011). 
Although no systematic information has been recorded on the coalitions that supported the designation of mayors, anecdotal accounts suggest that different sort of coalitions were formed. Oftentimes Golkar formed coalitions with PKB, while other times PDI-P formed coalitions with PPP. There is no systematic information either about the party affiliation of the newly elected mayors.

Some suggestive evidence can be obtained from the party affiliation of provincial governors. Provincial governors were elected using a similar system although at a higher administrative level. Of the 26 provinces that Indonesia had in 1999, 9 of them elected new governors in 1998 or early 1999 general. Hence, I focus on the remaining 17 provinces. Of these, in only 3 provinces one of the parties won by more than $50 \%$ of the votes. In all cases Golkar was the winning party and consequently a Golkar governor was elected. Among the remaining 14 provinces, 7 of them elected a governor that was a member of the party that obtained the highest number of votes. In 3 of the remaining provinces the new governor was a member of a party that formed a coalition with the most voted party in the province. To sum up, among provinces in which no party won $50 \%$ of the votes, $71 \%$ of the governors belong to the most voted party in the province or to a party that formed a coalition with the most voted party.

\section{Salary of Village Heads and Policies in kelurahan and desa}

The salary of elected village heads originates from the use or rental of communal or salary lands (tanah bengkok) (Sidel (2004)). The elected village heads can use this communal land during the length of their tenure. There is variation on how much land they obtain, but it typically enables them to have a comfortable life. Sidel (2004) reports that in some cases the amount of communal land is larger than the private land owned by the wealthiest landowners in the village. The salary of the appointed village heads comes from upper levels of government. There is an allocation for these salaries in the district level budget. There is no available information on the level of salaries of the elected village heads, but in general, it is believed that there are comparable to the salaries of the appointed village heads.

The two types of villages are subject to slightly different regulations as described in Law No 5 of year 1979. This law recognized the right of desa villages "to manage their own affairs" while decisions in kelurahan were assumed to be much closely monitored by the central government. However, during the Soeharto regime, most of these de jure differences were easily circumvented by the regime and de facto there were few differences between desa and kelurahan. ${ }^{9}$ The elected village head had virtually no autonomy to reach decisions independent of higher authorities. They were dependent on higher levels for directives and funds (Antlöv 2000). Both types of villages where financed by upper levels through block grants. Public goods were provided directly by the central government through INPRES programs in both desa and kelurahan (Antlöv and Eko 2012).

\footnotetext{
${ }^{9}$ Law No 5 of year 1979 also specified that desa villages right to "to manage their own affairs" did not mean "autonomy" (Antlöv 2000).
} 
The main financial cost on the conversion of desa into kelurahan related to the salary of the kelurahan village head and his staff. Since the salary of the kelurahan head has to be provided by the central government, expanding the number of kelurahan would impose a significant financial burden to the central government. To this date the salary of the desa village head continues to be raised from village sources. Although there has been some recent debate regarding the possibility of paying the salary of the desa village heads with central government funds, the reform has not been implemented using the same financial burden argument.

\section{Data Appendix}

The main data set used in this paper is constructed by merging different waves of the Indonesian Village Census PODES. Unfortunately, BPS (Statistical Agency of Indonesia) did not keep a consistent numerical code to merge observations across different waves of the PODES. I merge the different files based on village names. Out of the 66,000 villages of Indonesia, 7,000 do not have an exact match across these three waves. 4,000 additional observations have missing data for the electoral result in the village or for whether the village is kelurahan or desa. Finally, I restrict the sample to those districts in which there is enough variation in terms of the number of desa and kelurahan. In particular, I exclude from the analysis districts with fewer than 5 kelurahan or fewer than 5 desa. This reduces the sample by 12,000 additional observations.

The data on appointed village head turnover and characteristics was recorded on PODES 1996 and PODES 2000 waves.

The data on electoral results at the district level in the 1999 election was obtained from the electoral comission KPU.

The data on the electoral results at the district level for the Parliamentary elections of 1971, 1977, 1982, 1987, and 1992 used for the endogeneity robustness check, was generously provided by Professor Dwight King, from Northern Illinois University.

The data that on the timing of election of district mayors was generously shared by Emmanuel Skoufias. It contains information on the names, appointment and end dates of the last district mayor of the Soeharto period and the first district period of the democratic period.

The data on the occupational composition of villages used for robustness check in Section VI.B, was constructed from the National Socioeconomic Survey (SUSENAS). This survey is conducted on a nationally representative sample of households. I constructed aggregates at the village level for the responses given and match those to my baseline data. Since not all the villages in Indonesia had respondents in this household survey, the sample of analysis drops to 4,300 villages.

Finally, the data used for the democratic capital robustness check, was generously shared by Vivi Alatas, Abhijit Banerjee, Rema Hanna, Julia Tobias, and Benjamin Olken. This data was 
collected for the paper Alatas et al. (2010). Nine respondents were interviewed per village on a total of 258 kelurahan villages and 382 desa villages. The survey was conducted in late 2008 in the provinces of Central Java, South Sulawesi, and North Sumatra.

\section{Additional Robustness Checks}

\subsection{Propensity Score Matching Additional Discussion \& Results}

The propensity score matching algorithm, shown in Tables 2 and 3 in the main text, corresponds to block propensity score matching. This algorithm computes the propensity score independently for each province and imposes common support within each province. With the remaining observations, I compute the quintiles of the propensity score distribution of each province. Each of these five groups is assigned a dummy variable. For instance, one of the dummies takes value 1 if the estimate of the propensity score for a village is lower than the 20th percentile of the propensity score distribution in its district. Then I interact these dummies with the full set of province fixed effects. Finally, the dependent variable of interest is regressed on the kelurahan dummy and the full set of propensity score interval-province fixed effects interactions.

For illustration purposes Table A2 in this Online Appendix shows the results of the propensity score estimate for the largest province, Central Java, for three different set of covariates. As expected, the variables associated to urban characteristics have a positive effect in the probability of the village being classified as kelurahan. The propensity score matching results included in the paper use the full set of covariates shown in column (3) to compute the propensity score.

Figure A1 in this Online Appendix shows the distribution of the propensity score estimates in the full sample. In panel A we observe that, despite the fact that most kelurahan have a propensity score close to 1 , there is substantial heterogeneity in the urban characteristics of kelurahan. This is the case because even in very rural districts, kelurahan were formed in the surroundings of the capital of the subdistrict. (See section II.C for additional details on the process of kelurahan formation).

Although it is not visually perceptible from the figure in Panel B, there are also some desa villages with quite high propensity score estimates. This is also consistent with our earlier discussion,

which described that the process of conversion of villages from desa to kelurahan as they become more urban stopped in 1992.

For the case of Central Java the lowest propensity score estimate among kelurahan is 0.011, while the maximum propensity score estimate among desa is 0.97 . Hence, the interval of common support is $[0.011,0.97]$. Imposing the common support assumption eliminates 2, 600 observations, mainly desa villages. This represents a $40 \%$ reduction in the sample size for Central Java. 
Table A.3 in this Online Appendix provides a number of additional results and robustness checks for the propensity score matching results shown in the text.

First, panel A shows the LPM results which include province fixed effects instead of district fixed effects. As we can see, the results are strongest when using province fixed effects, highlighting that my preferred specification using district fixed effects is a highly demanding specification that removes some of the variation of interest.

Panel B reproduces the propensity score matching results in the main text (Table 3 ). Panel C shows the block propensity score matching results when imposing common support within districts, instead of within provinces. As we can see the sample size is reduced between $70 \%$ and $87 \%$ with respect to the baseline sample. Consequently, the statistical significance of some of the estimates is reduced. However, the point estimates show a remarkable stability with respect to the province-level propensity score matching results.

Finally panels D, E, and F show the robustness of the results to different propensity score matching algorithms. These results have been obtained using the psmatch2 command of Stata of Leuven and Sianesi (2003). In order to restrict matches within province I follow the authors' of psmatch2 advice and I compute the propensity score matching independently for each province and then I average the average treatment on the treated estimate for all the provinces.

Panels D and E implement nearest neighbor matching. Panel D restricts matches within a maximum caliper of 0.5, while Panel E restricts within radius matches. Finally, panel F performs kernel matching, in which all the observations in the control group are used to construct the counterfactual outcome. The weights of each observation are determined by kernel estimation. The particular kernel function used is the epanechnikov kernel and the bandwith is 0.06.

As we can see, despite these different propensity score matching algorithms use very different ways of estimating the counterfactual, the main set of results are robust. In particular, the results for districts that had lopsided elections, columns (5), (8) and (11) are particularly robust. Interestingly, the coefficient on column (2) becomes clearly negative, hence reinforcing the predictions of the theory.

\subsection{Endogeneity of the District Level Electoral Result}

In section 7.4 of the main text, I briefly describe a number of robustness checks that mitigate the concern that the district electoral result is endogenous to the electoral results in kelurahan villages. This sort of endogeneity is unlikely because of the small number of kelurahan in most districts. Panel A in Table A.5. of this Online Appendix shows how restricting the sample to districts where less than $20 \%$ of the population lives in kelurahan does not affect the results.

In Panel B, I show that the results are robust to an alternative classification of districts based on the inferred vote shares of desa villages. According to the model, desa residents vote sincerely. 
Hence, the district-level aggregation of vote shares in desa villages constitutes a better measure of sincere district-level vote shares. Unfortunately the district-level vote shares from desa villages are unobservable, since the electoral data available at the village level corresponds to the ranking of the three most voted parties, but not the corresponding vote shares.

To proxy for the district-level vote shares from desa villages I proceed as follows: I back out the sincere vote share of desa villages under the extreme assumption that most of the population in kelurahan voted for the winner party in the district. This enables me to find an upper bound in the frequency to which kelurahan villages could have been marginal in the district (i.e., those cases in which the electoral results in kelurahan villages could have altered the classification of the district as belonging to a large or tight victory of Golkar or PDI-P).

To illustrate this approach, let me define two type of kelurahan villages. In type 1 kelurahan, the most voted party in the kelurahan was also the most voted party in the district. In type 2 kelurahan, the most voted party in the kelurahan was not the most voted party in the district. The corresponding share of the district-level population living in these villages is denoted by $\gamma_{k, 1}$ and $\gamma_{k, 2}$, respectively. The share of the district-level population living in desa villages is given by $\gamma_{d}$, satisfying $\gamma_{k, 1}+\gamma_{k, 2}+\gamma_{d}=1$. The vote share of the most voted party in a given district, $\pi$, can be written as:

$$
\pi=\pi_{k, 1} \gamma_{k, 1}+\pi_{k, 2} \gamma_{k, 2}+\pi_{d} \gamma_{d}
$$

where $\pi_{i} i \in\{k 1, k 2, d\}$ is the vote share of the most voted in the corresponding subset of villages. In this context, $\pi_{d}$ can be understood as the sincere vote share, since, according to the model, desa villages vote sincerely. By undertaking certain assumptions about $\pi_{k, 1}$ and $\pi_{k, 2}$ I can obtain a prediction of $\pi_{d} \cdot{ }^{10} \mathrm{I}$ assume that $\pi_{k, 1}$ and $\pi_{k, 2}$ take values that generate the maximum congruence between the kelurahan and district level results, that are still consistent with the observed evidence. In particular, I assume that all villagers in kelurahan type 1 vote for the most voted party in the district (i.e., $\pi_{k, 1}=1$ ) and I assume that the most voted party in the district loses in kelurahan type 2 by the smallest possible margin (i.e., $\pi_{k, 2}=0.49$ ). Under these assumptions the sincere vote share of the most voted party in the district is:

$$
\hat{\pi}_{d}=\frac{1}{\gamma_{d}}\left[\pi-\gamma_{k, 1}-0.49 \gamma_{k, 2}\right]
$$

Similarly, the sincere vote share of the second most voted party, $\pi_{d}^{2 n d}$, is given by:

$$
\hat{\pi}_{d}^{2 n d}=\frac{1}{\gamma_{d}}\left[\pi^{2 n d}-0.51 \gamma_{k, 2}\right]
$$

Next, I explore how my results are affected by dividing districts in subsamples according to the estimated sincere vote shares, $\hat{\pi}_{d}$ and $\hat{\pi}_{d}^{2 n d}$, instead of the actual vote shares. These results are

\footnotetext{
${ }^{10}$ Note that, for each district, I have data on the actual district-level vote share, $\pi$, and on the share of population living in each type of village, $\gamma_{k, 1}, \gamma_{k, 2}$, and $\gamma_{d}$.
} 
displayed in Panel B of Table A5. As we can see, the results are broadly consistent with the main results shown in Table 3 of the main text. In particular, we still observe the pattern that is predicted by the theory: Golkar is more likely to win in kelurahan than in desa, in districts where Golkar won by a large margin (according to the sincere vote shares), while PDI-P is more likely to win in kelurahan than in desa in districts where PDI-P won by a large margin (according to the sincere vote shares). The former result is somewhat smaller in magnitude than the corresponding result in Table 3. However, it it is still significant at the $10 \%$ level. The decrease in the point estimate is consistent with the fact that only the districts where Golkar won by a very large margin remaining in this classification. It is likely that the equilibrium level of effort exerted by kelurahan heads is small in districts where one party wins by a very large margin (see discussion in footnote 44 in the main text). Overall, Panel B suggests that the results are robust to splitting the sample according to the sincere vote shares that would emerge if there was the maximum possible congruence between the kelurahan and district level results.

Finally, in Panel C of Table A5 I estimate the results when restricting the sample to the districts where the classification based on the actual vote shares is the same as the classification when using the inferred vote shares. Note that this restricts the sample to districts where the voting behavior of kelurahan could not have possibly affected the classification of the district. As we can see, the coefficients of the kelurahan dummy in districts where either Golkar or PDI-P won by a large margin are robust to this sample restriction. Overall, it is unlikely that the pattern of stronger electoral alignment of kelurahan to the district electoral result is mechanically generated by the presence of kelurahan, since this pattern is also present for districts where kelurahan could not have possibly been pivotal.

\subsection{Results on Electoral Violations}

In this section I present additional supporting evidence for the theoretical model presented in section 2 using data on the number of electoral violations. Measures of electoral violations are potentially a more direct measure of the effort exerted by village heads exert to manipulate voters, than measures based on electoral results. However, the limited geographic scope of the data on electoral violations forces us to be cautious in the interpretation, and hence the following results should be taken as suggestive additional evidence.

The data were collected by the electoral commission and made available in the publication Aribowo et. al. (2000). This publication contains information on 1,564 electoral violations that took place in East Java between the months of April and June of 1999. ${ }^{11}$ Most of the violations recorded

\footnotetext{
${ }^{11}$ The first democratic election post-Soeharto took place in June 1999. No agency kept a centralized collection of all the electoral violations that took place on that election. Consequently, I was only able to obtain measures of electoral violations that took place in East Java.
} 
consisted on the destruction of banners or property of some party by supporters or members of an opposing party. However, cases of intimidation or threats to some individuals were also recorded. The exact location of the electoral violation was not consistently collected. As a result I aggregate the number of electoral violations occurring at the subdistrict (kecamatan) level. I was able to match 275 of the subdistricts in the Electoral Violation dataset to my dataset. These represent approximately $44 \%$ of the subdistricts in East Java. Nevertheless, these 275 subdistricts contain information on 985 electoral violations, which represent $63 \%$ of the total amount of electoral violations that took place in East Java.

First, I use these data to document that electoral violations are more likely to occur in kelurahan villages than in desa villages. To show this, I regress the total number of electoral violations in a subdistrict on the number of kelurahan in a subdistrict. The results can be found in panel A, column 1, Table A6 in this Online Appendix. All the specifications include district fixed effects and my preferred set of covariates (geographic, religious, and facilities controls) aggregated at the subdistrict level. As we can see each additional kelurahan in the subdistrict increases the total number of electoral violations in the subdistrict by 0.49 , which represents an increase of $13 \%$ in the average number of electoral violations.

Second, I investigate the existence of heterogeneous results by exploring whether the effect of kelurahan on the number of electoral violations is different depending on which party wins the election at the district level and whether the margin of victory is large or tight. For this analysis, it is important to note that East Java, had a very particular political configuration. In particular, in out of the 37 districts of East Java, PDI-P turned out to be the most voted party in 23 of them, PKB in 13 of them, and PPP in 1 of them. ${ }^{12,13}$ Golkar was not the most voted party in any of them. Hence, the interpretation of this results is subject to the caveat that the province of East Java was not a representative province of the overall political configuration of the rest of the country.

Next, I divide the sample in districts where PDI-P or PKB won, and whether the margin of victory was large or tight. The results can be seen in Panels B, C, and D. As we can see from panel $\mathrm{B}$, the number of kelurahan is a significant determinant of the number of electoral violations only if either party won by a large margin, but not if PDI-P won by a tight margin.

Finally, in panels $\mathrm{C}$ and D, I explore the impact of kelurahan villages on the extent of electoral violations specifically targeted to one of the two major parties in the East Java. According to the theoretical model presented in the main text, when one of the parties is expected to win by a large margin all appointed village heads exert effort to support the likely winner. Hence, it is

\footnotetext{
${ }^{12}$ The leader of PKB, Abdurramah Wahid, was born and raised in East Java. He was born to a very influential family of East Java (his father was one of the leaders of the nationalist movement pro-independence). This explains to a great extent the predominance of PKB in East Java.

${ }^{13}$ Of the 37 districts in East Java, 27 are included in my baseline sample. Among those, PDI-P was the most voted party in 15 of them, PKB in 11 of them, and PPP in 1 of them.
} 
likely that they target their violations against the competitor party. In panel $\mathrm{C}$ the dependent variable corresponds to the number of electoral violations in which PKB was the victim. As we can see, kelurahan villages are a determinant of the electoral violations against PKB only in districts where PDI-P won by a large margin. Similarly, panel D shows that kelurahan villages are only a significant determinant of the extent of violations against PDI-P in districts where PKB won by a large margin. Hence, these results on the number of electoral violations are consistent with the predictions of the model. ${ }^{14,15}$

\subsection{Democratic Capital Hypothesis}

The flip side of the average result presented in Table 2 is that villages with an elected village head (desa villages) are less likely to vote for Soeharto's party. An alternative explanation for the average result might be the following: because these villages were able to hold village elections to select their leaders, their citizens might have developed a stronger democratic culture. Then, at the time of the 1999 election, they were less inclined to vote for Golkar, which represented the autocratic status quo, and they tended to vote more for reformist parties. Although this hypothesis cannot provide a rationale for the heterogeneous result, I examine its validity in this subsection. Nevertheless, it is important to emphasize that village elections were highly controlled by the Soeharto regime: candidates were prescreened by government officials and the election was nonpartisan. Moreover, village elections in desa took place every 8 years, while elections for the national, provincial, and district legislatures took place every 5 years, both in desa and kelurahan. Therefore, the differences in levels of democratic capital of desa and kelurahan might have been small.

In order to test this hypothesis, I examine data from a household survey conducted in 2008 for the project Alatas et al. (2010). In this survey several questions were asked about trust, participation in elections, participation in different types of organizations, motivation of voting behavior, and perception of corruption. In Table A7 of this Online Appendix, I explore the differences in the responses to these questions in desa and kelurahan villages. Column 2 shows the coefficients of specifications with no controls, while column 3 displays the coefficients when controls and district

\footnotetext{
${ }^{14} \mathrm{An}$ alternative approach would have been to explore the determinants of electoral violations perpetrated by supporters of a specific party. Unfortunately, the authorship of these violations could not always be established and, as a result, the data on actors of these violations is not consistently provided. Similarly, very few of these violations identify the village head as one of the authors. However, this is not surprising given the illegal nature of these electoral violations. Even in cases where the village head was the mastermind of the electoral violation, it is unlikely that the village head himself executed the violation, but a group of close supporters. Hence it may have been difficult to accuse the village head of the violation.

${ }^{15} \mathrm{It}$ is interesting to compare the sample means of the dependent variable in panels $\mathrm{C}$ and $\mathrm{D}$ across the different subsamples. There does not seem to be systematic differences in the average number of electoral violations against a specific party across districts. This mitigates the potential concern that PDI-P only won by a large margin in districts where there was a high number of electoral violations against PKB, and vice-versa.
} 
fixed effects are incorporated.

Notice that most of the differences in political participation become insignificant once the covariates of my preferred specification are included. This suggests that these covariates successfully control for the main determinants of voting behavior and political preferences. Still, there are some significant differences: villagers in kelurahan are more likely to agree with the statement that most people can be trusted than villagers in desa, which is not consistent with the democratic capital hypothesis. Also, kelurahan villagers are less likely to vote on the basis of the program of the candidate. Finally, there are no differences in the answers provided by desa and kelurahan villagers to questions about whether their vote was motivated by performance, religious or ethnic considerations. Interestingly, villagers of kelurahan are less likely to think there is a low level of corruption in the village government, which is consistent with the mechanism highlighted in this paper.

Overall, these data do not provide support for the democratic capital hypothesis, since there are no significant differences in the most important measures of democratic attitudes: trust, participation in elections, and participation in community organizations.

\subsection{Distance to the capital of the subdistrict}

A potential alternative explanation for the electoral results is the following: if parties exerts more campaign effort in their strongholds and parties have a preference to campaign in kelurahan than in desa, this could differentially activate voters in these two types of villages and confound the results.

In order to address this concern I, first, conducted a new set of robustness checks on distance to the sub-district office. The rationale for this is as follows: one possible reason why parties might decide to campaign more strongly in kelurahan than in desa is kelurahan's central location. As mentioned in the main text, kelurahan are typically located in the capital of the subdistrict and its surroundings. The average kelurahan in the sample is located within $3 \mathrm{~km}$ (1.8 miles) of the capital of the subdistrict, while desa are on average $13 \mathrm{~km}$ ( 8 miles) away from the capital of the subdistrict. Since the underlying empirical strategy relies on comparing the electoral behavior kelurahan and desa with similar characteristics, it is important to flexibly control for distance to the subdistrict.

The results of this robustness check can be found in Table A8 of this Online Appendix. As a first step, columns 1 and 4 adds to the baseline set of controls a quartic on the distance to the capital of the subdistrict. As we can see neither the point estimates nor the significance of the results is affected by these additional controls. ${ }^{16}$

\footnotetext{
${ }^{16}$ Controlling for a quartic on logged distance to the subdistrict, a quartic on distance to the district, or a quartic in the logged distance to the district leads to similar results. These additional results are omitted in the sake of brevity and are available from the author upon request.
} 
Next, in panel B and C, I estimate the following regression:

$$
\begin{aligned}
y_{v d}= & \beta_{11} k_{v d} \times P L+\beta_{2} \mathbf{1}_{\left\{\text {distance }_{v d}<c\right\}} \times P L+\beta_{31} k_{v d} \times \mathbf{1}_{\left\{\text {distance }_{v d}<c\right\}} \times P L \\
& \beta_{12} k_{v d} \times P J+\beta_{22} \mathbf{1}_{\left\{\text {distance }_{v d}<c\right\}} \times P J+\beta_{32} k_{v d} \times \mathbf{1}_{\left\{\text {distance }_{v d}<c\right\}} \times P J \\
& \beta_{13} k_{v d} \times G J+\beta_{23} \mathbf{1}_{\left\{\text {distance }_{v d}<c\right\}} \times G J+\beta_{33} k_{v d} \times \mathbf{1}_{\left\{\text {distance }_{v d}<c\right\}} \times G J \\
& \beta_{14} k_{v d} \times G L+\beta_{24} \mathbf{1}_{\left\{\text {distance }_{v d}<c\right\}} \times G L+\beta_{34} k_{v d} \times \mathbf{1}_{\left\{\text {distance }_{v d}<c\right\}} \times G L \\
& \beta_{15} k_{v d} \times O+\beta_{25} \mathbf{1}_{\left\{\text {distance }_{v d}<c\right\}} \times O+\beta_{35} k_{v d} \times \mathbf{1}_{\left\{\text {distance }_{v d}<c\right\}} \times O \\
& +\delta_{d}+\mathbf{X}_{v d}^{\prime} \theta+\varepsilon_{v d}
\end{aligned}
$$

where $y_{v d}$ takes value 1 if party $y$ obtained the highest number of votes in village $v$ of district $d, k_{v d}$ is a dummy that takes value 1 if village $v$ of district $d$ is a kelurahan (i.e., has an appointed village head), $\mathbf{1}_{\left\{\text {distance }_{v d}<c\right\}}$ is a dummy that takes value 1 if village $v$ of district $d$ is within $c$ kilometers of the capital of the subdistrict, PL (PJ) takes value 1 for districts where PDI-P wins by a large (tight) margin, GL (GJ) takes value 1 for districts where Golkar wins by a large (tight) margin, and O takes value 1 for districts where another party wins. Hence, this specification is similar to the baseline regression in the main text (equation (18)), but it now incorporates the distance dummy and its interaction. In columns 2 and 5 the threshold distance is chosen to be $1 \mathrm{~km}$ away, while in columns 3 and 6 the threshold is $0.5 \mathrm{~km}$ away.

Both columns 2 and 5, and columns 3 and 6 show similar results. First, notice that $\beta_{1 i} i \in$ 1, 2, 3, 4 estimates are remarkably similar to the baseline results reported in Table 3 , panel A in the paper. Moreover, the coefficients $\beta_{3 i}$ are small and statistically insignificant. These results suggests that the differences in electoral outcomes between desa and kelurahan follow the pattern predicted by the theory, both if these desa and kelurahan are close to the capital of the subdistrict or far away. $^{17}$

Notice that the significance of the distance dummy suggests that proximity to the capital of the subdistrict is one of the determinants of voting behavior. This could reflect a preference for parties to campaign in central locations or some other factor. However, overall these results suggest that these factors are appropriately controlled for in my preferred specification. In other words, even if parties had a preference for campaigning in the capital of the subdistrict, these results suggest that this preference was not different depending on whether the capital of the subdistirct was a kelurahan or a desa. Hence, a higher propensity to campaign in central locations could not account for the electoral results presented in the paper.

Admittedly, if political parties decide campaign more strongly in kelurahan than in desa, for reasons other than distance to the capital of the subdistrict, my results on electoral alignment could be confounded. However, as far as I know, there has not been any studies documenting a

\footnotetext{
${ }^{17}$ Furthermore, notice that the comparison of between desa and kelurahan in columns 3 and 6 is equivalent to comparing desa and kelurahan that are indeed subdistrict capitals.
} 
preference for parties of campaigning in kelurahan. The two most cited case studies on electoral campaigning in the 1999 election are Antlöv (2004) and Cederroth (2004). These studies do not mention at any point a preference of parties to campaign on kelurahan villages. Furthermore, I was able to interview one of these authors, Hans Antlöv, on my last visit to Indonesia on June 2012. He confirmed that he did not think that the village status as kelurahan or desa was an important determinant on the decision of parties of where to campaign.

\subsection{Appointed Village Heads Characteristics across Districts}

A potential alternative explanation for the electoral results is the following: if voters vote retrospectively and appointed village heads are more competent in Golkar strongholds, this could explain why Golkar is more likely to win in appointed villages in Golkar strongholds, while PDI-P is more likely to win in appointed villages in PDI-P strongholds. Although this alternative explanation could not account for the pattern of appointed village head turnover or the pattern of electoral violations, it is worth exploring its validity empirically.

Fortunately, there is some available data on the characteristics of appointed village heads and consequently it is possible to directly examine whether appointee characteristics vary across districts. In particular, for each district I compute the average age, education level, and gender of appointed village heads. Then, I regress these characteristics against a measure of strength of Golkar in the district.

The results can be found in Table A.9 in this Online Appendix. Panel A uses as measure of Golkar strength the vote share that Golkar obtained in the 1992 election (i.e., during the Soeharto

period). Panel B uses as measure of Golkar strength the vote share that Golkar obtained in the 1999 election.

Both panels show similar results: there is no evidence that the age, level of education or gender of the appointees differ systematically depending on the strength of Golkar in the districts. If anything the education results would suggest that Golkar strongholds have less educated appointees. If we take education as a proxy for competence, the evidence found would be at odds with the alternative hypothesis aforementioned. The results are similar when I partial out the measures of Golkar strength by measures of how rural is the district.

To sum up, there is no evidence to conclude that appointed village heads were more competent in Golkar strongholds than in PDI-P strongholds.

\subsection{Multinomial Choice Models}

In this section I proceed to analyze the question of interest using multinomial choice models. These models are motivated by the existence of a latent-unobserved dependent variable that determines 
the observed dependent variable. In the current setting the latent variable would correspond to the vote share of each party. Let us denote the vote share that party $j$ obtains in village $v$ by $V_{v j}$. This vote share depends on whether the village is a kelurahan or a desa and on other village-level characteristics:

$$
V_{v j}=k_{v} \beta_{j}+\mathbf{z}_{\mathbf{v}} \gamma_{\mathbf{j}}+\epsilon_{v j}
$$

where $\mathbf{z}_{\mathbf{v}}$ is a vector of village level covariates, $\gamma_{\mathbf{j}}$ is the vector of the corresponding coefficients, and $\epsilon_{v j}$ is a village-level preference shock.

I do not observe village-level vote shares but a qualitative variable denoting which was the the most voted party in the village.

$$
y_{v}=\left\{\begin{array}{c}
1 \text { if } V_{v 1} \geq V_{v j} \text { for all } j \\
2 \text { if } V_{v 2} \geq V_{v j} \text { for all } j \\
\ldots \\
J \text { if } V_{v J} \geq V_{v j} \text { for all } j
\end{array}\right.
$$

I estimate the parameters of equation (16) using a multinomial logit model and a nested logit. Notice that if the underlying assumptions of these models are satisfied, I will be able to estimate the parameters of equation (16), in particular the effect of being a kelurahan on the vote share of different parties.

The results are presented in Table A.10 in this Online Appendix. Panel A shows the multinomial logit, where the base category is PDI-P being the most voted party in the village. The results are consistent with the main set of results presented in Table 3 of the paper: Golkar is more likely to win in kelurahan than in desa, in all districts except in those where PDI-P wins by a large margin. ${ }^{18}$ Hence, the results highlight that the advantage of Golkar over PDI-P in kelurahan disappears in PDI-P strongholds. As we can see from column 1 the marginal effect is close to 0 and statistically insignificant.

The multinomial logit specification enables us to find some additional results. Recall that the results in Table 3, column 8, in the main text, shows that in PDI-P strongholds, PDI-P was more likely to win in kelurahan than in desa. The multinomial logit results in columns 1 and 2 suggest that this is driven by a lower propensity of third parties to win in kelurahan. A likely explanation of this result is that kelurahan heads found easier to persuade voters to vote for PDI-P when they would otherwise have voted for third parties, than from voters that have traditionally voted for Golkar.

\footnotetext{
${ }^{18}$ For instance, in districts where Golkar wins by a large margin, the log odds ratio of Golkar victory relative to PDI-P victory is 0.36 units higher in kelurahan than in desa.
} 
The multinomial logit results highlight that the pattern of voting between desa and kelurahan is markedly different in PDI-P strongholds than in other districts. And, that these differences are related to the interplay between Golkar and PDI-P. As we can see, in all districts, the likelihood of voting for third parties is lower in kelurahan than in desa. In all districts, but in PDI-P strongholds Golkar is more likely to win in kelurahan than in desa. What this suggest is that the particular electoral behavior in PDI-P strongholds is driven by the large drop in the likelihood of supporting Golkar that kelurahan experience in those districts. The model presented in this paper provides an intuitive explanation for this pattern that otherwise would be difficult to account for: in PDI$\mathrm{P}$ strongholds kelurahan heads had strong incentives to show their alignment with PDI-P and consequently, persuaded voters to vote for PDI-P.

Despite these results are interesting, notice that the probit results provide a closer test to the theoretical predictions: the model predicts that if party $\mathrm{X}$ is expected to win by a large margin in the district, kelurahan will support party $\mathrm{X}$. This is regardless of whether party $\mathrm{X}$ is PDI-P or Golkar. The model does not make any predictions of which parties are likely to lose from this additional support to party $\mathrm{X}$.

The main limitation of the multinomial logit model is that it assumes Independence of Irrelevant Alternatives (IIA, henceforth). In other words, it assumes that the ratio of probability of Golkar victory with respect to PDI-P victory does not depend on the presence of other alternatives. In order to relax this assumption I estimate a nested logit model in which the individuals are assumed to choose between two nests: Golkar and opposition parties. Within opposition parties we have PDI-P and third parties. The IIA is assumed to hold within nests, but not across nests. An important caveat is that the nested logit is computationally intensive and the model with the full set of covariates did not converge. As a result, I estimate the nested logit using only a subset of covariates. (See notes in Table A10 for further details). For comparison, Panel B estimates the multinomial logit using the same subset of covariates. As we can see, the results of the nested logit are similar to those of the multinomial logit, highlighting that the imposition of the IIA is not affecting the results.

\subsection{Robustness of Turnover Results}

Table 4 in the main text of the paper shows the turnover results controlling for my preferred set of controls (geographic, religious intensity and facilities controls). Table A11 in this Online Appendix shows the robustness of these results to the inclusion of alternative sets of controls. Panel A shows the results when no controls are included (other than the district fixed effects). Panel B shows the results when only geographic controls are included. Finally, panel $\mathrm{C}$ shows the results when adding an exhaustive set of controls: geographic factors, religious intensity control, facilities, incidence of conflict, presence of the military, availability of natural resources, and concession of the IDT 
poverty alleviation program. Remarkably, none of these variations on the set of controls included affects the magnitude or statistical significance of the estimates.

Table A12 shows the turnover results for more narrow intervals of the margin of victory of the district election. Columns 2 to 5 correspond to districts where PDI-P was the most voted party in the 1999 election, while columns 6 to 9 correspond to districts where Golkar was the most voted party. Panel A shows the main results where the dependent variable is a dummy that takes value one if there was an appointed village head turnover in the year following the 1999 election. As described in section V.B, the results become statistically significant and have the sign predicted by the theory in in districts where the election was close. As also predicted by the theory, there is not a clear patter of political retaliation of appointed village heads if the election was lopsided.

Panel B shows the results of a Placebo exercise. In particular, I obtain a measure of turnover of appointed village heads prior to the 1999 election: the dependent variable takes value one if the appointed village head reports having been in office for 0 years in the PODES survey conducted in 1996. Hence, this dependent variable can be interpreted as turnover in a randomly selected year of the latter years of the Soeharto regime. The model presented in section 2 provides an intuitive explanation to the results in Panel A: the turnover result are a natural consequence of the decision of appointed village officials to align with different parties after the fall of a nondemocratic regime. A natural extension of the model will not predict a particular turnover pattern before the fall of the nondemocratic regime. The placebo test presented in panel B corroborates this finding, since most of the coefficients are not statistically significant and the point estimates do not follow any particular pattern. This placebo test also helps mitigatigating the concern that the turnover effects presented in panel A are driven by villages in which turnover is always particularly high. As we can see there is no evidence of high turnover prior to 1999 in districts where the 1999 election was close. Figure 1 in the main text of paper provides a graphical illustration of the results in panels A and B. In particular it plots the coefficients $\beta_{1}+\beta_{2}$, i.e., the difference in predicted probability of turnover in villages where Golkar won in the 1999 election and villages where another party won, conditional on districts where a new mayor already took office by the year 2000 . 


\section{$5 \quad$ Additional References}

Alatas, Vivi, Abhijit Banerjee, Rema Hanna, Benjamin Olken, and Julia Tobias, "How to Target the Poor: Evidence from a Field Experiment in Indonesia," American Economic Review, forthcoming, 2010.

Antlöv, Hans "Village Governance in Indonesia - Past, Present and Future Challenges" Paper presented at the PERCIK conference "Dynamics of Local Politics in Indonesia"; 2000.

Antlöv, Hans, and Sutoro Eko "Village and Sub-District Functions in Decentralized Indonesia" Paper to DSF's Closing Workshop, 12-13 March 2012"; 2012.

Aribowo, Muhammad Asfar, Kacung Marijan, and Zaidun, Kekerasan Politik Pemilu 1999, (Rungkut, Surabaya ; HIPOTESA, 2000).

E. Leuven and B. Sianesi, "PSMATCH2: Stata module to perform full Mahalanobis and propensity score matching, common support graphing, and covariate imbalance testing"; 2003.

Sidel, John "Bossism and democracy in the Philippines, Thailand, and Indonesia: towards an alternative framework for the study of 'local strongmen"'. In: Harriss, John and Stokke, Kristin and Tornquist, Olle, (eds.) Politicising democracy: the new local politics of democratisation. International political economy series . Palgrave Macmillan, Basingstoke, UK; 2004. 
Table A.1

Effects of Appointed Official on Support for Golkar

\begin{tabular}{|c|c|c|c|c|c|}
\hline & \multicolumn{5}{|c|}{ Dependent variable: Golkar wins in 1999} \\
\hline & $(1)$ & $(2)$ & (3) & (4) & $(5)$ \\
\hline kelurahan & $\begin{array}{c}\mathbf{0 . 0 7 3 9} * * * \\
(0.028)\end{array}$ & $\begin{array}{l}\mathbf{0 . 0 0 6 5} \\
(0.012)\end{array}$ & $\begin{array}{c}\mathbf{0 . 0 5 7 5} * * * \\
(0.012)\end{array}$ & $\begin{array}{c}\mathbf{0 . 0 5 7 3} * * * \\
(0.012)\end{array}$ & $\begin{array}{c}\mathbf{0 . 0 5 5 2} * * * \\
(0.012)\end{array}$ \\
\hline urban & & & $\begin{array}{c}-0.0206^{*} \\
(0.011)\end{array}$ & $\begin{array}{c}-0.0184 * \\
(0.011)\end{array}$ & $\begin{array}{c}-0.0212 * \\
(0.011)\end{array}$ \\
\hline$\% \mathrm{HH}$ in agr & & & $\begin{array}{c}-0.0036 \\
(0.003)\end{array}$ & $\begin{array}{l}-0.0033 \\
(0.003)\end{array}$ & $\begin{array}{l}-0.0030 \\
(0.003)\end{array}$ \\
\hline$\%$ land in agr & & & $\begin{array}{l}0.0003 \\
(0.000)\end{array}$ & $\begin{array}{l}0.0003 \\
(0.000)\end{array}$ & $\begin{array}{l}0.0003 \\
(0.000)\end{array}$ \\
\hline high altitude & & & $\begin{array}{c}0.0255^{* *} \\
(0.011)\end{array}$ & $\begin{array}{c}0.0274 * * \\
(0.011)\end{array}$ & $\begin{array}{c}0.0276^{* * *} * \\
(0.011)\end{array}$ \\
\hline log population & & & $\begin{array}{l}0.0348 \\
(0.569)\end{array}$ & $\begin{array}{l}0.4695 \\
(0.415)\end{array}$ & $\begin{array}{l}0.4584 \\
(0.420)\end{array}$ \\
\hline population density & & & $\begin{array}{l}-0.0012 \\
(0.001)\end{array}$ & $\begin{array}{l}-0.0010 \\
(0.001)\end{array}$ & $\begin{array}{l}-0.0010 \\
(0.001)\end{array}$ \\
\hline distance sub-distr office & & & $\begin{array}{l}0.0002 \\
(0.000)\end{array}$ & $\begin{array}{l}0.0002 \\
(0.000)\end{array}$ & $\begin{array}{l}0.0002 \\
(0.000)\end{array}$ \\
\hline distance district capital & & & $\begin{array}{l}0.0000 \\
(0.000)\end{array}$ & $\begin{array}{l}0.0000 \\
(0.000)\end{array}$ & $\begin{array}{l}0.0000 \\
(0.000)\end{array}$ \\
\hline num mosques ${ }^{\S}$ & & & & $\begin{array}{c}0.0175^{* * * *} \\
(0.003)\end{array}$ & $\begin{array}{c}0.0173 * * * \\
(0.003)\end{array}$ \\
\hline num prayerhouse ${ }^{\S}$ & & & & $\begin{array}{l}-0.0007 \\
(0.001)\end{array}$ & $\begin{array}{l}-0.0006 \\
(0.001)\end{array}$ \\
\hline num churches ${ }^{\S}$ & & & & $\begin{array}{c}-0.0119^{* *} \\
(0.005)\end{array}$ & $\begin{array}{c}-0.0118^{* *} \\
(0.005)\end{array}$ \\
\hline num hindu temple ${ }^{\S}$ & & & & $\begin{array}{l}0.0167 \\
(0.015)\end{array}$ & $\begin{array}{l}0.0156 \\
(0.015)\end{array}$ \\
\hline num $\mathrm{TVs}^{\S}$ & & & & & $\begin{array}{c}0.0002 * \\
(0.000)\end{array}$ \\
\hline num hospitals ${ }^{\S}$ & & & & & $\begin{array}{l}0.0516 \\
(0.043)\end{array}$ \\
\hline num maternity hospitals ${ }^{\S}$ & & & & & $\begin{array}{l}-0.0102 \\
(0.020)\end{array}$ \\
\hline num polyclinics ${ }^{\S}$ & & & & & $\begin{array}{c}0.0576^{*} \\
(0.030)\end{array}$ \\
\hline num puskesmas ${ }^{\S}$ & & & & & $\begin{array}{c}0.0280 * * \\
(0.013)\end{array}$ \\
\hline num kindergarden ${ }^{\S}$ & & & & & $\begin{array}{c}-0.0287 * * * \\
(0.008)\end{array}$ \\
\hline num primary school ${ }^{\S}$ & & & & & $\begin{array}{l}0.0018 \\
(0.002)\end{array}$ \\
\hline num high school ${ }^{\S}$ & & & & & $\begin{array}{l}-0.0002 \\
(0.005)\end{array}$ \\
\hline District Fixed Effects & No & Yes & Yes & Yes & Yes \\
\hline Observations & 43,394 & 43,394 & 43,394 & 43,394 & 43,394 \\
\hline Adjusted R-squared & 0.00161 & 0.368 & 0.375 & 0.378 & 0.379 \\
\hline
\end{tabular}

Notes: $\S$ Per 1,000 villagers. Robust Standard errors clustered at the district level in parenthesis. The unit of observation is the village level. Linear Probability Model regressions. The dependent variable is a dummy that takes value 1 if Golkar was the most voted party in the village in the Parliamentary election of 1999 and 0 otherwise. Regressions in columns (3) to (6) include a quartic in the percentage of households in agriculture and log population. $* * * \mathrm{p}<0.01, * * \mathrm{p}<0.05, *$ $\mathrm{p}<0.1$. 
Table A.2

Propensity Score Matching. Probit Estimation for Central Java

\begin{tabular}{|c|c|c|c|}
\hline Dependent variable: kelurahan village & (1) & (2) & (3) \\
\hline urban & $\begin{array}{c}0.6744 * * * \\
(0.116)\end{array}$ & $\begin{array}{c}0.6806^{* * *} \\
(0.118)\end{array}$ & $\begin{array}{c}0.5425^{* * *} * \\
(0.124)\end{array}$ \\
\hline$\% \mathrm{HH}$ in agr & $\begin{array}{c}-0.0739^{* * *} \\
(0.025)\end{array}$ & $\begin{array}{c}-0.0758^{* * *} \\
(0.025)\end{array}$ & $\begin{array}{c}-0.0667^{* * *} \\
(0.026)\end{array}$ \\
\hline$\%$ land in agr & $\begin{array}{c}-0.0089^{* * *} \\
(0.003)\end{array}$ & $\begin{array}{c}-0.0099^{* * *} \\
(0.003)\end{array}$ & $\begin{array}{c}-0.0086^{* * *} \\
(0.003)\end{array}$ \\
\hline high altitude & $\begin{array}{l}-0.1459 \\
(0.149)\end{array}$ & $\begin{array}{l}-0.1917 \\
(0.154)\end{array}$ & $\begin{array}{l}-0.1941 \\
(0.156)\end{array}$ \\
\hline $\log$ population & $\begin{array}{r}-91.8839 \\
(64.758)\end{array}$ & $\begin{array}{c}-108.3397 \\
(67.537)\end{array}$ & $\begin{array}{c}-112.4741^{*} \\
(68.018)\end{array}$ \\
\hline population density & $\begin{array}{c}0.1194 * * * \\
(0.022)\end{array}$ & $\begin{array}{c}0.1037 * * * \\
(0.022)\end{array}$ & $\begin{array}{c}0.1092^{* * *} * \\
(0.023)\end{array}$ \\
\hline distance sub-distr office & $\begin{array}{c}-0.0693 * * * \\
(0.018)\end{array}$ & $\begin{array}{c}-0.0695 * * * \\
(0.018)\end{array}$ & $\begin{array}{c}-0.0572 * * * \\
(0.019)\end{array}$ \\
\hline distance district capital & $\begin{array}{l}0.0005 \\
(0.003)\end{array}$ & $\begin{array}{l}0.0023 \\
(0.003)\end{array}$ & $\begin{array}{l}0.0030 \\
(0.003)\end{array}$ \\
\hline num mosques ${ }^{\S}$ & & $\begin{array}{c}-0.1057^{*} \\
(0.061)\end{array}$ & $\begin{array}{c}-0.1324^{* *} \\
(0.065)\end{array}$ \\
\hline num prayerhouse ${ }^{\S}$ & & $\begin{array}{c}-0.1939 * * * \\
(0.035)\end{array}$ & $\begin{array}{c}-0.2087 * * * \\
(0.036)\end{array}$ \\
\hline num churches ${ }^{\S}$ & & $\begin{array}{c}-0.2874 \\
(0.191)\end{array}$ & $\begin{array}{c}-0.4325^{* *} \\
(0.204)\end{array}$ \\
\hline num hindu temple ${ }^{\S}$ & & $\begin{array}{l}-0.6553 \\
(0.754)\end{array}$ & $\begin{array}{l}-0.5541 \\
(0.762)\end{array}$ \\
\hline num $\mathrm{TVs}^{\S}$ & & & $\begin{array}{c}0.0039 * * * \\
(0.001)\end{array}$ \\
\hline num hospitals ${ }^{\S}$ & & & $\begin{array}{l}1.0172 \\
(0.778)\end{array}$ \\
\hline num maternity hospitals ${ }^{\S}$ & & & $\begin{array}{l}1.2664 \\
(0.819)\end{array}$ \\
\hline num polyclinics ${ }^{\S}$ & & & $\begin{array}{l}0.5364 \\
(0.616)\end{array}$ \\
\hline num puskesmas ${ }^{\S}$ & & & $\begin{array}{l}-0.5168 \\
(0.453)\end{array}$ \\
\hline num kindergarden ${ }^{\S}$ & & & $\begin{array}{l}0.0215 \\
(0.136)\end{array}$ \\
\hline num primary school ${ }^{\S}$ & & & $\begin{array}{l}0.0790 \\
(0.051)\end{array}$ \\
\hline num high school ${ }^{\S}$ & & & $\begin{array}{c}0.3025^{* * *} \\
(0.105)\end{array}$ \\
\hline Observations & 6,575 & 6,575 & 6,575 \\
\hline
\end{tabular}

Notes: $\S$ Per 1,000 villagers. Standard errors in parentheses. Probit regressions that include a full set of district dummies. The unit of observation is the village level. The dependent variable takes value 1 if the village is a kelurahan and 0 if it is a desa. All regressions include a quartic of the variables percentage of households in aggriculture and $\log$ population. $* * * \mathrm{p}<0.01, * *$ $\mathrm{p}<0.05,{ }^{*} \mathrm{p}<0.1$. 
Table A.3 Robustness of Propensity Score Matching Results

\begin{tabular}{|c|c|c|c|c|c|c|c|c|c|c|c|c|}
\hline & \multicolumn{5}{|c|}{ Dependent variable: Golkar wins in 1999} & \multirow[b]{2}{*}{ Neither Won } & \multicolumn{6}{|c|}{ Dependent Variable: PDI-P wins in 1999} \\
\hline & Whole sample & $\begin{array}{l}\text { PDI-P Won } \\
\text { Large } 1999\end{array}$ & $\begin{array}{l}\text { PDI-P Just Won } \\
\quad 1999\end{array}$ & $\begin{array}{c}\text { Golkar Just Won } \\
1999\end{array}$ & $\begin{array}{l}\text { Golkar Won } \\
\text { Large } 1999\end{array}$ & & Whole sample & $\begin{array}{l}\text { PDI-P Won } \\
\text { Large } 1999\end{array}$ & $\begin{array}{l}\text { PDI-P Just Won } \\
1999\end{array}$ & $\begin{array}{c}\text { Golkar Just Won } \\
1999\end{array}$ & $\begin{array}{l}\text { Golkar Won } \\
\text { Large } 1999\end{array}$ & Neither Won \\
\hline & (1) & (2) & (3) & (4) & (5) & (6) & (7) & (8) & (9) & (10) & (11) & (12) \\
\hline \multirow[b]{2}{*}{ Kelurahan dummy } & \multicolumn{12}{|c|}{ A. Linear Probability Model Province Fixed Effects } \\
\hline & $\begin{array}{c}0.0650^{* * * *} \\
(0.013)\end{array}$ & $\begin{array}{l}-0.0030 \\
(0.014)\end{array}$ & $\begin{array}{c}0.0684 * * * \\
(0.021)\end{array}$ & $\begin{array}{c}0.1359 * * * \\
(0.032)\end{array}$ & $\begin{array}{l}0.0438^{*} \\
(0.022)\end{array}$ & $\begin{array}{l}0.0763 \\
(0.049)\end{array}$ & $\begin{array}{l}-0.0244 \\
(0.027)\end{array}$ & $\begin{array}{c}0.0606^{* *} \\
(0.021)\end{array}$ & $\begin{array}{l}-0.0311 \\
(0.042)\end{array}$ & $\begin{array}{c}-0.0975 * * \\
(0.034)\end{array}$ & $\begin{array}{l}-0.0259 \\
(0.018)\end{array}$ & $\begin{array}{l}0.0200 \\
(0.044)\end{array}$ \\
\hline Observations & 43,394 & 15,430 & 9,114 & 5,946 & 7,378 & 5,526 & 43,394 & 15,430 & 9,114 & 5,946 & 7,378 & 5,526 \\
\hline \multirow[t]{2}{*}{ Adjusted R-squared } & 0.331 & 0.062 & 0.139 & 0.058 & 0.092 & 0.135 & 0.237 & 0.050 & 0.066 & 0.071 & 0.082 & 0.077 \\
\hline & \multicolumn{12}{|c|}{ B. Propensity Score Matching within Province } \\
\hline Kelurahan dummy & $\begin{array}{c}0.0325^{* * *} \\
(0.008)\end{array}$ & $\begin{array}{l}0.0014 \\
(0.009)\end{array}$ & $\begin{array}{l}0.0343 \\
(0.030)\end{array}$ & $\begin{array}{c}0.1363^{* * *} \\
(0.037)\end{array}$ & $\begin{array}{c}0.0473^{* * *} \\
(0.015)\end{array}$ & $\begin{array}{l}0.0278 \\
(0.022)\end{array}$ & $\begin{array}{l}-0.0030 \\
(0.013)\end{array}$ & $\begin{array}{c}0.0328^{* * *} \\
(0.004)\end{array}$ & $\begin{array}{l}-0.0080 \\
(0.046)\end{array}$ & $\begin{array}{l}-0.0991 * \\
(0.052)\end{array}$ & $\begin{array}{l}-0.0207^{*} \\
(0.011)\end{array}$ & $\begin{array}{l}-0.0225 \\
(0.045)\end{array}$ \\
\hline Observations & 19,206 & 7,814 & 4,303 & 1,822 & 3,378 & 1,889 & 19,206 & 7,814 & 4,303 & 1,822 & 3,378 & 1,889 \\
\hline \multirow[t]{2}{*}{ Adjusted R-squared } & 0.428 & 0.0465 & 0.121 & 0.0457 & 0.0973 & 0.0913 & 0.225 & 0.0203 & 0.0249 & 0.0616 & 0.0739 & 0.0500 \\
\hline & \multicolumn{12}{|c|}{ C. Propensity Score Matching within District } \\
\hline Kelurahan dummy & $\begin{array}{c}0.0368^{* * * *} \\
(0.013)\end{array}$ & $\begin{array}{l}-0.0018 \\
(0.013)\end{array}$ & $\begin{array}{l}0.0183 \\
(0.033)\end{array}$ & $\begin{array}{c}0.1691 * * * \\
(0.041)\end{array}$ & $\begin{array}{c}0.0614^{* * *} \\
(0.020)\end{array}$ & $\begin{array}{l}0.0223 \\
(0.027)\end{array}$ & $\begin{array}{l}-0.0125 \\
(0.016)\end{array}$ & $\begin{array}{l}0.0259 \\
(0.021)\end{array}$ & $\begin{array}{l}-0.0021 \\
(0.052)\end{array}$ & $\begin{array}{c}-0.1718 * * * \\
(0.043)\end{array}$ & $\begin{array}{r}-0.0100 \\
(0.018)\end{array}$ & $\begin{array}{l}-0.0534 \\
(0.050)\end{array}$ \\
\hline \multirow[t]{2}{*}{ Adjusted R-squared } & $\begin{array}{l}9,361 \\
0.519 \\
\end{array}$ & $\begin{array}{r}3,528 \\
0.0534 \\
\end{array}$ & $\begin{array}{l}2,072 \\
0.160 \\
\end{array}$ & $\begin{array}{c}815 \\
0.105 \\
\end{array}$ & $\begin{array}{l}2,253 \\
0.127 \\
\end{array}$ & $\begin{array}{c}693 \\
0.248 \\
\end{array}$ & $\begin{array}{l}9,361 \\
0.412 \\
\end{array}$ & $\begin{array}{r}3,528 \\
0.0874 \\
\end{array}$ & $\begin{array}{c}2,072 \\
0.0514 \\
\end{array}$ & $\begin{array}{r}815 \\
0.0473 \\
\end{array}$ & $\begin{array}{r}2,253 \\
0.0828 \\
\end{array}$ & $\begin{array}{c}693 \\
0.0768 \\
\end{array}$ \\
\hline & \multicolumn{12}{|c|}{ D. Average Treatment on the Treated 1 to 1 Propensity Score Matching, Capiler 0.5} \\
\hline Kelurahan dummy & 0.067 & -0.0414 & 0.0208 & 0.1393 & 0.0522 & 0.0482 & -0.0289 & 0.0909 & -0.0236 & -0.0571 & -0.0075 & 0.0644 \\
\hline \multirow[t]{2}{*}{ Observations } & 44,953 & 14,453 & 7,242 & 4,049 & 6,688 & 18,483 & 44,953 & 14,453 & 7,242 & 4,049 & 6,688 & 18,483 \\
\hline & \multicolumn{12}{|c|}{ E. Average Treatment on the Treated 1 to 1 Propensity Score Matching, Radius } \\
\hline Kelurahan dummy & 0.0378 & -0.0385 & 0.0507 & 0.1064 & 0.1188 & 0.0305 & 0.0108 & 0.0414 & -0.052 & -0.0627 & -0.0734 & 0.0463 \\
\hline \multirow[t]{2}{*}{ Observations } & 44,953 & 14,453 & 7,242 & 4,049 & 6,688 & 18,483 & 44,953 & 14,453 & 7,242 & 4,049 & 6,688 & 18,483 \\
\hline & \multicolumn{12}{|c|}{ F. Average Treatment on the Treated Propensity Score Matching, Kernel } \\
\hline Kelurahan dummy & 0.0611 & -0.0216 & -0.0129 & 0.2023 & 0.0961 & 0.0482 & -0.0227 & 0.0684 & -0.0085 & -0.1058 & -0.0455 & 0.0644 \\
\hline Observations & 44,953 & 14,453 & 7,242 & 4,049 & 6,688 & 18,483 & 44,953 & 14,453 & 7,242 & 4,049 & 6,688 & 18,483 \\
\hline $\begin{array}{l}\text { Notes: The unit of o } \\
\text { columns (7) to (12) } \\
\text { including province fi } \\
\text { using as independent } \\
\text { C shows the results } \\
\text { different matching al } \\
\text { level. Standard Error }\end{array}$ & $\begin{array}{l}\text { hing is co } \\
\text { the the AT } \\
\text { tre bootstr }\end{array}$ & $\begin{array}{l}\text { geograp } \\
\text { within d } \\
\text { differen } \\
\text { tandard }\end{array}$ & $\begin{array}{l}\text { gious, and } \\
\text { anel B imp } \\
\text { ce is avera } \\
\mathrm{f} \text { Panel C a }\end{array}$ & $\begin{array}{l}\text { B to F sho } \\
\text { es controls. } \\
\text { common st } \\
\text { the corresp } \\
\text { bootstrapp }\end{array}$ & $\begin{array}{l}\text { B to C d } \\
\text { vithin pro } \\
\text { subsamp } \\
\text { use of ins }\end{array}$ & $\begin{array}{l}\text { hing resu } \\
\text { lock prop } \\
\text { anel C im } \\
\text { els D, E, a }\end{array}$ & $\begin{array}{l}\text { erent matchin } \\
\text { re matching. } \\
\text { nmon support }\end{array}$ & $\begin{array}{l}\text { gorithms. } \\
1 \text { B shows } \\
\text { hin distric }\end{array}$ & $\begin{array}{l}\text { sults when the } \\
\text { els D, E, and F } \\
\text { d of Stata. Star }\end{array}$ & $\begin{array}{l}\text { hows the Lin } \\
\text { all the model } \\
\text { atching is con } \\
\text { timate the pro } \\
\text { ard errors of P }\end{array}$ & $\begin{array}{l}\text { of } 1999 \text { a } \\
\text { robability } \\
\text { estimated u } \\
\text { ed within } p \\
\text { ity score } \mathrm{w} \\
\text { A are clus }\end{array}$ & $\begin{array}{l}\text { otherwise. Fo } \\
1 \text { results when } \\
\text { probit model } \\
\text { e, while pane } \\
\text { province using } \\
\text { at the province }\end{array}$ \\
\hline
\end{tabular}


Table A.4

Endogeneity Check

\begin{tabular}{|c|c|c|c|c|c|}
\hline & $(1)$ & $(2)$ & (3) & $(4)$ & $(5)$ \\
\hline & \multicolumn{5}{|c|}{ Panel A: Dependent variable: Propensity Score of kelurahan Villages } \\
\hline Vote Share Golkar 1971 & $\begin{array}{l}-0.0006 \\
(0.048)\end{array}$ & & & & \\
\hline Vote Share Golkar 1977 & & $\begin{array}{l}-0.0609 \\
(0.069)\end{array}$ & & & \\
\hline Vote Share Golkar 1982 & & & $\begin{array}{l}-0.0923 \\
(0.072)\end{array}$ & & \\
\hline Vote Share Golkar 1987 & & & & $\begin{array}{l}-0.1114 \\
(0.096)\end{array}$ & \\
\hline Vote Share Golkar 1992 & & & & & $\begin{array}{l}-0.0086 \\
(0.017)\end{array}$ \\
\hline Share of Rural Households & $\begin{array}{c}-0.6097 * * * \\
(0.034)\end{array}$ & $\begin{array}{c}-0.5897 * * * \\
(0.039)\end{array}$ & $\begin{array}{c}-0.5720 * * * \\
(0.045)\end{array}$ & $\begin{array}{c}-0.5708 * * * \\
(0.047)\end{array}$ & $\begin{array}{c}-0.6102 * * * \\
(0.033)\end{array}$ \\
\hline Constant & $\begin{array}{c}0.7305 * * * \\
(0.027)\end{array}$ & $\begin{array}{c}0.7622 * * * \\
(0.041)\end{array}$ & $\begin{array}{c}0.7768 * * * \\
(0.040)\end{array}$ & $\begin{array}{c}0.7970 * * * \\
(0.061)\end{array}$ & $\begin{array}{c}0.7420 * * * \\
(0.029)\end{array}$ \\
\hline $\begin{array}{l}\text { Observations } \\
\text { R-squared }\end{array}$ & $\begin{array}{l}2,295 \\
0.333 \\
\end{array}$ & $\begin{array}{l}2,307 \\
0.332 \\
\end{array}$ & $\begin{array}{l}2,307 \\
0.334 \\
\end{array}$ & $\begin{array}{l}2,307 \\
0.333 \\
\end{array}$ & $\begin{array}{l}2,307 \\
0.331 \\
\end{array}$ \\
\hline \multicolumn{6}{|c|}{ Panel B. Dependent Variable: Average Propensity Score of kelurahan Villages } \\
\hline Vote Share Golkar $1971^{\S}$ & $\begin{array}{l}-0.0208 \\
(0.075)\end{array}$ & & & & \\
\hline Vote Share Golkar $1977^{\S}$ & & $\begin{array}{l}-0.0467 \\
(0.092)\end{array}$ & & & \\
\hline Vote Share Golkar $1982^{\S}$ & & & $\begin{array}{l}-0.0760 \\
(0.090)\end{array}$ & & \\
\hline Vote Share Golkar $1987^{\S}$ & & & & $\begin{array}{l}-0.2015 \\
(0.126)\end{array}$ & \\
\hline Vote Share Golkar $1992^{\S}$ & & & & & $\begin{array}{l}-0.0285 \\
(0.033)\end{array}$ \\
\hline Constant & $\begin{array}{c}0.3888 * * * \\
(0.015)\end{array}$ & $\begin{array}{c}0.3933^{* * * *} \\
(0.015)\end{array}$ & $\begin{array}{c}0.3933 * * * \\
(0.015)\end{array}$ & $\begin{array}{c}0.3933^{* * * *} \\
(0.015)\end{array}$ & $\begin{array}{c}0.3933 * * * \\
(0.015)\end{array}$ \\
\hline Observations & 152 & 155 & 155 & 155 & 155 \\
\hline R-squared & 0.001 & 0.002 & 0.005 & 0.016 & 0.005 \\
\hline
\end{tabular}

Notes: Standard errors in parenthesis. In Panel A, the unit of observation is the village level. The dependent variable is the propensity score of kelurahan villages. This propensity score is computed adding as controls geographic, religious, and facilities controls but no district fixed effects. In Panel B, the unit of observation is the district level. The dependent variable is the average propensity score of kelurahan villages in each district. $\S$ These independent variables have been partialled out by the share of rural households in the district. ${ }^{* * *} \mathrm{p}<0.01, * * \mathrm{p}<0.05, * \mathrm{p}<0.1$ 
Table A.5

Robustness Check Endogenous District-Level Electoral Results

\begin{tabular}{|c|c|c|c|c|c|c|c|c|c|c|c|c|}
\hline & \multicolumn{5}{|c|}{ "Dependent variable: Golkar wins in 1999} & \multirow[b]{2}{*}{$\begin{array}{c}\text { Neither Won } \\
(6) \\
\end{array}$} & \multicolumn{6}{|c|}{ "Dependent Variable: PDI-P wins in 1999} \\
\hline & $\begin{array}{c}\text { Whole sample } \\
\text { (1) }\end{array}$ & $\begin{array}{c}\text { PDI-P Won } \\
\text { Large } 1999 \\
(2) \\
\end{array}$ & $\begin{array}{c}\text { PDI-P Just } \\
\text { Won } 1999 \\
(3) \\
\end{array}$ & $\begin{array}{c}\text { Golkar Just } \\
\text { Won } 1999 \\
(4) \\
\end{array}$ & $\begin{array}{c}\text { Golkar Won } \\
\text { Large } 1999 \\
(5) \\
\end{array}$ & & $\begin{array}{c}\text { Whole sample } \\
\text { (7) } \\
\end{array}$ & $\begin{array}{c}\text { PDI-P Won } \\
\text { Large } 1999 \\
(8) \\
\end{array}$ & $\begin{array}{c}\text { PDI-P Just } \\
\text { Won } 1999 \\
(9) \\
\end{array}$ & $\begin{array}{c}\text { Golkar Just } \\
\text { Won } 1999 \\
(10) \\
\end{array}$ & $\begin{array}{c}\text { Golkar Won } \\
\text { Large } 1999 \\
(11) \\
\end{array}$ & $\begin{array}{c}\text { Neither Won } \\
(12) \\
\end{array}$ \\
\hline & \multicolumn{12}{|c|}{ A. Dropping districts where kelurahan population $>20 \%$ of total population } \\
\hline Kelurahan dummy & $\begin{array}{c}0.0548 * * * \\
(0.014)\end{array}$ & $\begin{array}{l}-0.0067 \\
(0.017)\end{array}$ & $\begin{array}{c}0.0643^{* *} \\
(0.029)\end{array}$ & $\begin{array}{c}0.1582 * * * \\
(0.037)\end{array}$ & $\begin{array}{c}0.0604^{* * *} \\
(0.021)\end{array}$ & $\begin{array}{l}0.0675 \\
(0.042)\end{array}$ & $\begin{array}{l}-0.0167 \\
(0.018)\end{array}$ & $\begin{array}{c}0.0502 * * \\
(0.021)\end{array}$ & $\begin{array}{l}-0.0368 \\
(0.048)\end{array}$ & $\begin{array}{l}-0.0792 \\
(0.052)\end{array}$ & $\begin{array}{c}-0.0404 * \\
(0.023)\end{array}$ & $\begin{array}{l}-0.0175 \\
(0.049)\end{array}$ \\
\hline Observations & 38,592 & 14,326 & 8,466 & 4,900 & 5,497 & 5,403 & 38,592 & 14,326 & 8,466 & 4,900 & 5,497 & 5,403 \\
\hline Adjusted R-squared & 0.347 & 0.0852 & 0.149 & 0.0700 & 0.109 & 0.144 & 0.328 & 0.0821 & 0.0743 & 0.0934 & 0.0969 & 0.127 \\
\hline Districts & 145 & 54 & 28 & 17 & 28 & 18 & 145 & 54 & 28 & 17 & 28 & 18 \\
\hline & \multicolumn{12}{|c|}{ B. Dividing the sample according to inferred district vote share from desa villages } \\
\hline Kelurahan dummy & $\begin{array}{c}0.0552^{* * *} \\
(0.012)\end{array}$ & $\begin{array}{l}0.0004 \\
(0.019)\end{array}$ & $\begin{array}{c}0.1041 * * * \\
(0.029)\end{array}$ & $\begin{array}{c}0.0976 * * * \\
(0.027)\end{array}$ & $\begin{array}{l}0.0224^{*} \\
(0.013)\end{array}$ & $\begin{array}{l}0.0402 \\
(0.025)\end{array}$ & $\begin{array}{l}-0.0208 \\
(0.014)\end{array}$ & $\begin{array}{c}0.0516^{* *} \\
(0.022)\end{array}$ & $\begin{array}{c}-0.0696^{*} \\
(0.040)\end{array}$ & $\begin{array}{c}-0.0670^{* *} \\
(0.028)\end{array}$ & $\begin{array}{l}0.0021 \\
(0.013)\end{array}$ & $\begin{array}{l}-0.0136 \\
(0.028)\end{array}$ \\
\hline Observations & 43,394 & 11,255 & 9,145 & 7,719 & 5,405 & 9,870 & 43,394 & 11,255 & 9,145 & 7,719 & 5,405 & 9,870 \\
\hline Adjusted R-squared & 0.382 & 0.081 & 0.227 & 0.189 & 0.126 & 0.253 & 0.343 & 0.086 & 0.135 & 0.239 & 0.129 & 0.238 \\
\hline Districts & 0.379 & 0.0753 & 0.221 & 0.182 & 0.117 & 0.248 & 0.339 & 0.0800 & 0.128 & 0.232 & 0.119 & 0.233 \\
\hline & \multicolumn{12}{|c|}{ C. Restricted sample to districts where kelurahan could not have affected the electoral result } \\
\hline Kelurahan dummy & $\begin{array}{c}0.0396 * * * \\
(0.014)\end{array}$ & $\begin{array}{l}0.0004 \\
(0.019)\end{array}$ & $\begin{array}{l}0.1243 * \\
(0.060)\end{array}$ & $\begin{array}{l}-0.0457 \\
(0.089)\end{array}$ & $\begin{array}{l}0.0224^{*} \\
(0.013)\end{array}$ & $\begin{array}{l}0.0770^{*} \\
(0.040)\end{array}$ & $\begin{array}{l}0.0108 \\
(0.017)\end{array}$ & $\begin{array}{c}0.0516 * * \\
(0.022)\end{array}$ & $\begin{array}{l}0.0074 \\
(0.112)\end{array}$ & $\begin{array}{l}0.1282 \\
(0.088)\end{array}$ & $\begin{array}{l}0.0021 \\
(0.013)\end{array}$ & $\begin{array}{l}-0.0072 \\
(0.049)\end{array}$ \\
\hline Observations & 26,739 & 11,255 & 3,786 & 1,508 & 5,405 & 4,785 & 26,739 & 11,255 & 3,786 & 1,508 & 5,405 & 4,785 \\
\hline Adjusted R-squared & 0.485 & 0.081 & 0.165 & 0.140 & 0.126 & 0.123 & 0.430 & 0.086 & 0.123 & 0.158 & 0.129 & 0.140 \\
\hline Districts & 0.482 & 0.0753 & 0.156 & 0.121 & 0.117 & 0.115 & 0.427 & 0.0800 & 0.114 & 0.139 & 0.119 & 0.132 \\
\hline
\end{tabular}


Table A.6

Evidence on Electoral Violations

\begin{tabular}{|c|c|c|c|c|c|c|c|}
\hline \multirow[b]{2}{*}{ Dependent Variables: } & \multicolumn{7}{|c|}{ A. Types of Electoral Violations } \\
\hline & $\begin{array}{c}\text { Total Number of } \\
\text { Violations } \\
\text { (1) }\end{array}$ & $\begin{array}{c}\text { Destruction of } \\
\text { banners and } \\
\text { party symbols } \\
\text { (2) } \\
\end{array}$ & $\begin{array}{l}\text { Violent attacks } \\
\text { and } \\
\text { intimidation. } \\
\text { (3) }\end{array}$ & $\begin{array}{c}\text { Violence against } \\
\text { party members } \\
\text { or supporters } \\
\text { (4) }\end{array}$ & $\begin{array}{l}\text { Violence against } \\
\text { the general } \\
\text { public } \\
\text { (5) }\end{array}$ & $\begin{array}{l}\text { Violence against } \\
\text { members of the } \\
\text { electoral } \\
\text { comission } \\
(6) \\
\end{array}$ & $\begin{array}{c}\text { Clashes within } \\
\text { parties } \\
(7)\end{array}$ \\
\hline Sample Mean Dep. Var & 3.582 & 2.542 & 0.156 & 0.342 & 0.342 & 0.062 & 0.138 \\
\hline Number of kelurahan & $\begin{array}{c}0.4968^{* * * *} \\
(0.165)\end{array}$ & $\begin{array}{c}0.2597 * * \\
(0.100)\end{array}$ & $\begin{array}{c}0.0493 * * \\
(0.020)\end{array}$ & $\begin{array}{c}0.0925 * * \\
(0.041)\end{array}$ & $\begin{array}{l}0.0346 \\
(0.028)\end{array}$ & $\begin{array}{l}0.0156 \\
(0.011)\end{array}$ & $\begin{array}{l}0.0452 \\
(0.030)\end{array}$ \\
\hline Observations & 275 & 275 & 275 & 275 & 275 & 275 & 275 \\
\hline R-squared & 0.401 & 0.390 & 0.264 & 0.210 & 0.381 & 0.215 & 0.265 \\
\hline Number of districts & 27 & 27 & 27 & 27 & 27 & 27 & 27 \\
\hline \multirow[t]{2}{*}{ Dependent Variable: } & \multicolumn{4}{|c|}{ B. Heterogenous Results: Total number of Electoral Violations } & & & \\
\hline & Whole Sample & $\begin{array}{c}\text { PDI-P Won } \\
\text { Large } \\
\end{array}$ & PDI-P Just Won & PKB Won Large & & & \\
\hline Sample Mean Dep. Var & 3.582 & 5.528 & 2.889 & 2.857 & & & \\
\hline Number of kelurahan & $\begin{array}{c}0.4968^{* * *} \\
(0.165)\end{array}$ & $\begin{array}{l}1.7122 * \\
(0.774)\end{array}$ & $\begin{array}{l}0.3378 \\
(0.360)\end{array}$ & $\begin{array}{c}0.3667 * * \\
(0.144)\end{array}$ & & & \\
\hline Observations & 275 & 36 & 108 & 105 & & & \\
\hline R-squared & 0.401 & 0.928 & 0.303 & 0.613 & & & \\
\hline Number of districts & 27 & 6 & 9 & 9 & & & \\
\hline \multirow[t]{2}{*}{ Dependent Variable: } & \multicolumn{4}{|c|}{ C. Number of Electoral Violations in which PKB was the victim } & & & \\
\hline & Whole Sample & $\begin{array}{c}\text { PDI-P Won } \\
\text { Large }\end{array}$ & PDI-P Just Won & PKB Won Large & & & \\
\hline Sample Mean Dep. Var & 0.287 & 0.306 & 0.157 & 0.371 & & & \\
\hline Number of kelurahan & $\begin{array}{l}0.0099 \\
(0.021)\end{array}$ & $\begin{array}{c}0.3385 * * * \\
(0.042)\end{array}$ & $\begin{array}{l}-0.0121 \\
(0.017)\end{array}$ & $\begin{array}{l}-0.0280 \\
(0.075)\end{array}$ & & & \\
\hline Observations & 275 & 36 & 108 & 105 & & & \\
\hline R-squared & 0.340 & 0.985 & 0.399 & 0.389 & & & \\
\hline Number of districts & 27 & 6 & 9 & 9 & & & \\
\hline \multirow[t]{2}{*}{ Dependent Variable: } & \multicolumn{4}{|c|}{ D. Number of Electoral Violations where PDI-P was the victim } & & & \\
\hline & Whole Sample & $\begin{array}{c}\text { PDI-P Won } \\
\text { Large } \\
\end{array}$ & PDI-P Just Won & PKB Won Large & & & \\
\hline Sample Mean Dep. Var & 0.069 & 0.083 & 0.056 & 0.067 & & & \\
\hline Number of kelurahan & $\begin{array}{l}0.0049 \\
(0.014)\end{array}$ & $\begin{array}{l}0.0839 \\
(0.045)\end{array}$ & $\begin{array}{l}0.0162 \\
(0.016)\end{array}$ & $\begin{array}{c}0.0558 * \\
(0.027)\end{array}$ & & & \\
\hline Observations & 275 & 36 & 108 & 105 & & & \\
\hline R-squared & 0.339 & 0.926 & 0.311 & 0.662 & & & \\
\hline Number of districts & 27 & 6 & 9 & 9 & & & \\
\hline
\end{tabular}


Table A.7

Robustness Checks: Democratic Capital Hypothesis

\begin{tabular}{|c|c|c|c|}
\hline \multirow[b]{2}{*}{ Dependent variables: } & \multirow[b]{2}{*}{$\begin{array}{c}\text { Sample Mean } \\
\text { (1) }\end{array}$} & \multicolumn{2}{|c|}{ Coefficients on the kelurahan dummy } \\
\hline & & $\begin{array}{c}\text { No controls } \\
\text { (2) }\end{array}$ & $\begin{array}{c}\text { All controls \& Distr } \\
\text { (3) }\end{array}$ \\
\hline \multicolumn{4}{|c|}{$\% \mathrm{HH}$ in the village that agree with the statement that $[\ldots]$ can be trusted } \\
\hline most people & 0.261 & $\begin{array}{c}0.0880^{* * *} \\
(0.0331)\end{array}$ & $\begin{array}{l}0.1018 * * \\
(0.0435)\end{array}$ \\
\hline \multirow[t]{2}{*}{ people in this halmet } & 0.642 & -0.0117 & 0.0192 \\
\hline & & $(0.0337)$ & $(0.0456)$ \\
\hline the village head & 0.768 & $\begin{array}{l}-0.0086 \\
(0.0294)\end{array}$ & $\begin{array}{l}-0.0441 \\
(0.0398)\end{array}$ \\
\hline \multirow[t]{2}{*}{ the local government } & 0.644 & $0.0692 *$ & 0.0143 \\
\hline & & $(0.0361)$ & $(0.0409)$ \\
\hline the president & 0.713 & $\begin{array}{l}0.0596 * * \\
(0.0296)\end{array}$ & $\begin{array}{c}0.0138 \\
(0.0362)\end{array}$ \\
\hline
\end{tabular}

$\% \mathrm{HH}$ in the village that participate in each type of organization

government
religious
recreational
political

$\begin{array}{lcc}0.306 & -0.0823^{*} & 0.0193 \\ & (0.0486) & (0.0471) \\ 0.565 & -0.1477^{* *} & -0.0405 \\ & (0.0591) & (0.0319) \\ 0.0971 & -0.0659 * * * & -0.0281 \\ & (0.0244) & (0.0250) \\ 0.0309 & -0.0010 & -0.0094 \\ & (0.0110) & (0.0150) \\ 0.935 & & \\ & 0.0034 & -0.0034 \\ & (0.0149) & (0.0205)\end{array}$

$\%$ of $\mathrm{HH}$ that agree with the statement that his/her vote is influenced by $[\ldots]$ factor

ethnic
religious
program of candidate
performance of candidate

$\%$ of $\mathrm{HH}$ that think there is low corruption at the [...] level
0.250

0.401

0.483

0.491

$\begin{array}{cc}-0.0338 & -0.0240 \\ (0.0351) & (0.0468) \\ -0.0745^{*} & -0.0555 \\ (0.0399) & (0.0517) \\ 0.0020 & -0.1152^{* *} \\ (0.0399) & (0.0490) \\ 0.0329 & -0.0681 \\ (0.0402) & (0.0499)\end{array}$

\author{
central government
}

district government

village government

$\begin{array}{ccc}0.109 & -0.0290 & -0.0020 \\ & (0.0192) & (0.0252) \\ 0.241 & -0.0800^{* *} & -0.0567 \\ & (0.0319) & (0.0370) \\ 0.634 & -0.1326^{* * *} & -0.1213^{* * *} \\ & (0.0361) & (0.0443)\end{array}$

Notes: Robust Standard errors clustered at the district level in parenthesis. The unit of observation is the village level and the econometric model is Linear Probability Model. Column (2) displays the coefficient of the kelurahan dummy in a regression in which the dependent variable is as defined by each row. No further controls are added in column (2). Column (3) displays the coefficient of the kelurahan dummy when geographic, religious, and facilities controls and district fixed effects are also included. The data belong to a survey conducted in 2008 for the project "How to Target the Poor: Evidence from a Field Experiment in Indonesia" (Vivi Alatas, Abhijit Banerjee, Ben Olken, Rema Hanna, and Julia Tobias). In this survey a random sample of villages were interviewed in 5 districts on the provinces of Central Java and South Sulawesi. There are 198 villages in the sample: 59 kelurahan and 139 desa. ${ }^{* * *} \mathrm{p}<0.01, * * \mathrm{p}<0.05, * \mathrm{p}<0.1$. 
Table A.8 Robustness Check Distance Capital of the Subdistrict (Interactions Specification)

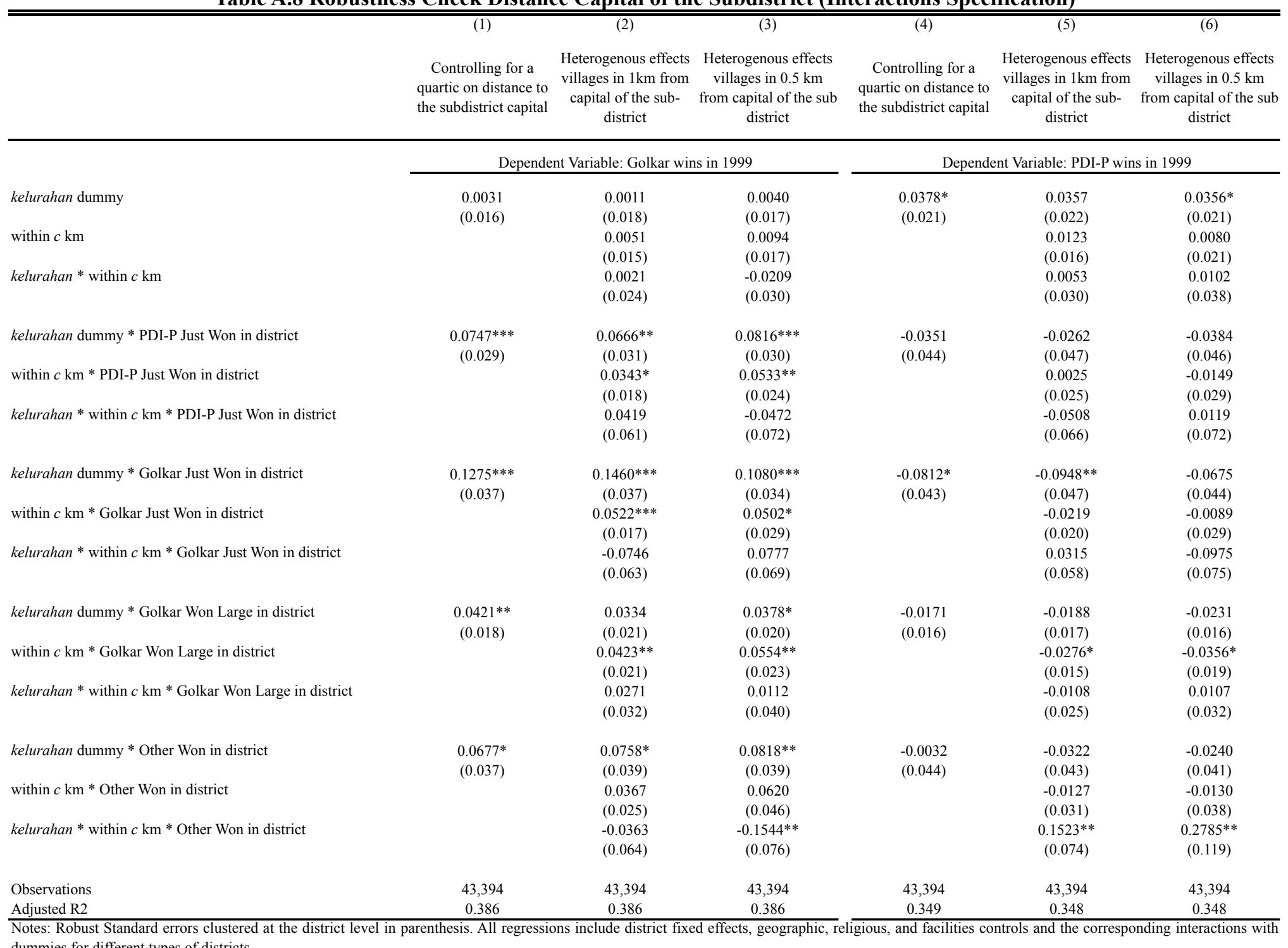

Notes: Robust Standard errors clustered
dummies for different types of districts. 
Table A.9. Appointed Village Heads Characteristics across Districts

\begin{tabular}{|c|c|c|c|c|c|c|}
\hline & \multicolumn{6}{|c|}{ Dependent Variable: Average Characteristics of Appointed Village Heads in 1996} \\
\hline & \multicolumn{2}{|c|}{ Age } & \multicolumn{2}{|c|}{ Education } & \multicolumn{2}{|c|}{ Gender } \\
\hline & $\begin{array}{c}\text { No Controls } \\
\text { (1) }\end{array}$ & $\begin{array}{l}\text { Controls } \\
\text { (2) } \\
\end{array}$ & $\begin{array}{c}\text { No Controls } \\
\text { (3) } \\
\end{array}$ & $\begin{array}{c}\text { Controls } \\
(4) \\
\end{array}$ & $\begin{array}{c}\text { No Controls } \\
\text { (5) }\end{array}$ & $\begin{array}{c}\text { Controls } \\
(6)\end{array}$ \\
\hline & \multicolumn{6}{|c|}{ A. Vote Share Golkar 1992 election } \\
\hline Vote Share Golkar 1992 & $\begin{array}{l}-2.6311 \\
(2.299)\end{array}$ & $\begin{array}{l}-2.4554 \\
(6.901)\end{array}$ & $\begin{array}{l}-0.1085 \\
(0.234)\end{array}$ & $\begin{array}{l}-0.4490 \\
(0.583)\end{array}$ & $\begin{array}{l}0.0048 \\
(0.013)\end{array}$ & $\begin{array}{l}-0.0137 \\
(0.040)\end{array}$ \\
\hline \multirow[t]{2}{*}{ R-squared } & $\begin{array}{c}192 \\
0.010\end{array}$ & $\begin{array}{c}192 \\
0.344\end{array}$ & $\begin{array}{c}192 \\
0.002\end{array}$ & $\begin{array}{c}192 \\
0.482\end{array}$ & $\begin{array}{c}192 \\
0.000\end{array}$ & $\begin{array}{c}192 \\
0.361\end{array}$ \\
\hline & \multicolumn{6}{|c|}{ B. Vote Share Golkar in 1999 election } \\
\hline Vote Share Golkar 1999 & $\begin{array}{l}3.4104 \\
(3.055)\end{array}$ & $\begin{array}{l}3.7282 \\
(4.905)\end{array}$ & $\begin{array}{l}-0.0606 \\
(0.417)\end{array}$ & $\begin{array}{l}-0.2644 \\
(0.591)\end{array}$ & $\begin{array}{c}-0.1305^{*} \\
(0.069)\end{array}$ & $\begin{array}{l}-0.0427 \\
(0.062)\end{array}$ \\
\hline Observations & 192 & 192 & 192 & 192 & 192 & 192 \\
\hline R-squared & 0.228 & 0.345 & 0.329 & 0.479 & 0.156 & 0.363 \\
\hline
\end{tabular}

Notes: Standard errors in parenthesis. The unit of observation is the district level. Each dependent variable corresponds to the avearage characteristics of appointed village heads in each district. The set of controls includes geographic, religious, and facilities controls averaged at the district level and province fixed effects. ${ }^{* * *} \mathrm{p}<0.01,{ }^{* *} \mathrm{p}<0.05,{ }^{*} \mathrm{p}<0.1$ 
Table A.10 Multinomial Choice Models

\begin{tabular}{|c|c|c|c|c|c|c|c|c|}
\hline & (1) & (2) & (3) & (4) & (5) & (6) & (7) & (8) \\
\hline & \multicolumn{8}{|c|}{ Dependent Variable: most voted party (mvp) } \\
\hline & \multicolumn{2}{|c|}{ PDI-P Won Large 1999} & \multicolumn{2}{|c|}{ PDI-P Just Won 1999} & \multicolumn{2}{|c|}{ Golkar Just Won 1999} & \multicolumn{2}{|c|}{ Golkar Won Large 1999} \\
\hline & $\mathrm{mpv}=$ Golkar & $\mathrm{mpv}=3 \mathrm{rd}$ parties & $\mathrm{mpv}=$ Golkar & $\mathrm{mpv}=3 \mathrm{rd}$ parties & $\mathrm{mpv}=$ Golkar & $\mathrm{mpv}=3 \mathrm{rd}$ parties & $\mathrm{mpv}=$ Golkar & $\mathrm{mpv}=3 \mathrm{rd}$ parties \\
\hline & \multicolumn{8}{|c|}{ A. Multinomial Logit. Full Set of Controls. PDI-P is the Base Outcome } \\
\hline Kelurahan dummy & $\begin{array}{l}0.0739 \\
(0.170)\end{array}$ & $\begin{array}{c}-0.6465 * * * \\
(0.223)\end{array}$ & $\begin{array}{c}0.7151 * * * \\
(0.191)\end{array}$ & $\begin{array}{l}-0.1671 \\
(0.261)\end{array}$ & $\begin{array}{c}0.5589 * * * \\
(0.209)\end{array}$ & $\begin{array}{l}-0.0922 \\
(0.255)\end{array}$ & $\begin{array}{l}0.3640 \\
(0.243)\end{array}$ & $\begin{array}{l}-0.1132 \\
(0.394)\end{array}$ \\
\hline Marginal Effect & $\begin{array}{l}0.0075 \\
(0.013)\end{array}$ & $\begin{array}{c}-0.0248 * * * \\
(0.006)\end{array}$ & $\begin{array}{c}0.1296 * * * \\
(0.039)\end{array}$ & $\begin{array}{l}-0.0541 \\
(0.035)\end{array}$ & $\begin{array}{c}0.1318^{* * *} \\
(0.034)\end{array}$ & $\begin{array}{c}-0.0572 * * * \\
(0.019)\end{array}$ & $\begin{array}{c}0.0166^{* *} \\
(0.007)\end{array}$ & $\begin{array}{c}-0.0121^{*} \\
(0.007)\end{array}$ \\
\hline $\begin{array}{l}\text { Observations } \\
\text { Log-likelihood } \\
\text { Pseudo R-sq } \\
\end{array}$ & $\begin{array}{c}15,430 \\
-9,336 \\
0.130 \\
\end{array}$ & $\begin{array}{c}15,430 \\
-9,336 \\
0.130 \\
\end{array}$ & $\begin{array}{c}9,114 \\
-7,879 \\
0.152 \\
\end{array}$ & $\begin{array}{c}9,114 \\
-7,879 \\
0.152 \\
\end{array}$ & $\begin{array}{c}5,946 \\
-5,259 \\
0.134 \\
\end{array}$ & $\begin{array}{c}5,946 \\
-5,259 \\
0.134 \\
\end{array}$ & $\begin{array}{c}7,378 \\
-3,662 \\
0.151 \\
\end{array}$ & $\begin{array}{c}7,378 \\
-3,662 \\
0.151 \\
\end{array}$ \\
\hline Pseudo R-sq & \multicolumn{8}{|c|}{ B. Multinomial Logit. Subset of Controls. PDI-P is the Base Outcome } \\
\hline Kelurahan dummy & $\begin{array}{l}0.1825 \\
(0.159)\end{array}$ & $\begin{array}{c}-0.7342 * * * \\
(0.236)\end{array}$ & $\begin{array}{c}0.7100 * * * \\
(0.197)\end{array}$ & $\begin{array}{l}-0.2616 \\
(0.260)\end{array}$ & $\begin{array}{c}0.5275^{* * *} \\
(0.219)\end{array}$ & $\begin{array}{l}-0.2332 \\
(0.274)\end{array}$ & $\begin{array}{c}0.3786^{*} \\
(0.208)\end{array}$ & $\begin{array}{l}-0.0633 \\
(0.365)\end{array}$ \\
\hline Marginal Effect & $\begin{array}{l}0.0170 \\
(0.013)\end{array}$ & $\begin{array}{c}-0.0297 * * * \\
(0.007)\end{array}$ & $\begin{array}{c}0.1331 * * * \\
(0.040)\end{array}$ & $\begin{array}{c}-0.0680 * * \\
(0.034)\end{array}$ & $\begin{array}{c}0.1370 * * * \\
(0.036)\end{array}$ & $\begin{array}{c}-0.0685 * * * \\
(0.019)\end{array}$ & $\begin{array}{c}0.0166 * * \\
(0.008)\end{array}$ & $\begin{array}{l}-0.0121 \\
(0.008)\end{array}$ \\
\hline $\begin{array}{l}\text { Observations } \\
\text { Log-likelihood } \\
\text { Pseudo R-sq } \\
\end{array}$ & $\begin{array}{c}15,430 \\
-9594 \\
0.105 \\
\end{array}$ & $\begin{array}{c}15,430 \\
-9594 \\
0.105 \\
\end{array}$ & $\begin{array}{l}9,114 \\
-8092 \\
0.129 \\
\end{array}$ & $\begin{array}{l}9,114 \\
-8092 \\
0.129 \\
\end{array}$ & $\begin{array}{l}5,946 \\
-5355 \\
0.118 \\
\end{array}$ & $\begin{array}{l}5,946 \\
-5355 \\
0.118 \\
\end{array}$ & $\begin{array}{l}7,378 \\
-3742 \\
0.132 \\
\end{array}$ & $\begin{array}{l}7,378 \\
-3742 \\
0.132 \\
\end{array}$ \\
\hline Pseudo R-sq & \multicolumn{8}{|c|}{ C. Nested Logit. Subset of Controls. PDI-P is the Base Outcome } \\
\hline Kelurahan dummy & $\begin{array}{l}-0.0144 \\
(0.244)\end{array}$ & & $\begin{array}{c}0.5058^{*} \\
(0.280)\end{array}$ & & $\begin{array}{l}0.5202 * \\
(0.305)\end{array}$ & & $\begin{array}{l}0.4419 \\
(0.340)\end{array}$ & \\
\hline Observations & 15,216 & & 4,917 & & 5,298 & & 3,327 & \\
\hline Log-likelihood & $-5,119$ & & $-1,682$ & & $-1,703$ & & -904 & \\
\hline
\end{tabular}

Notes: Robust Standard errors clustered at the district level in parenthesis. The unit of observation is the village level. The dependent variable corresponds to the most voted party. The base category is PDI-P being the most voted party. The econometric specifications are estimated in different subsamples depending on whether PDI-P or Golkar won and whether the margin of victory was larger or smaller than 10 percentage points. Panel B and C use as controls percentage of households in agricultural occupations, share of land devoted to agriculture, a quartic in log population, population density and district fixed effects. The nested logit specifies two nests, voting for Golkar or voting for opposition parties. The opposition parties nest comprises PDI-P and 3rd parties. The coefficient shown tell us how much higher is the logs-odds ratio of voting for Golkar versus voting for opposition parties in kelurahan than in desa. ${ }^{* * *} \mathrm{p}<0.01,{ }^{* *} \mathrm{p}<0.05,{ }^{*} \mathrm{p}<0.1$. 
Table A.11 Turnover Robustness Checks

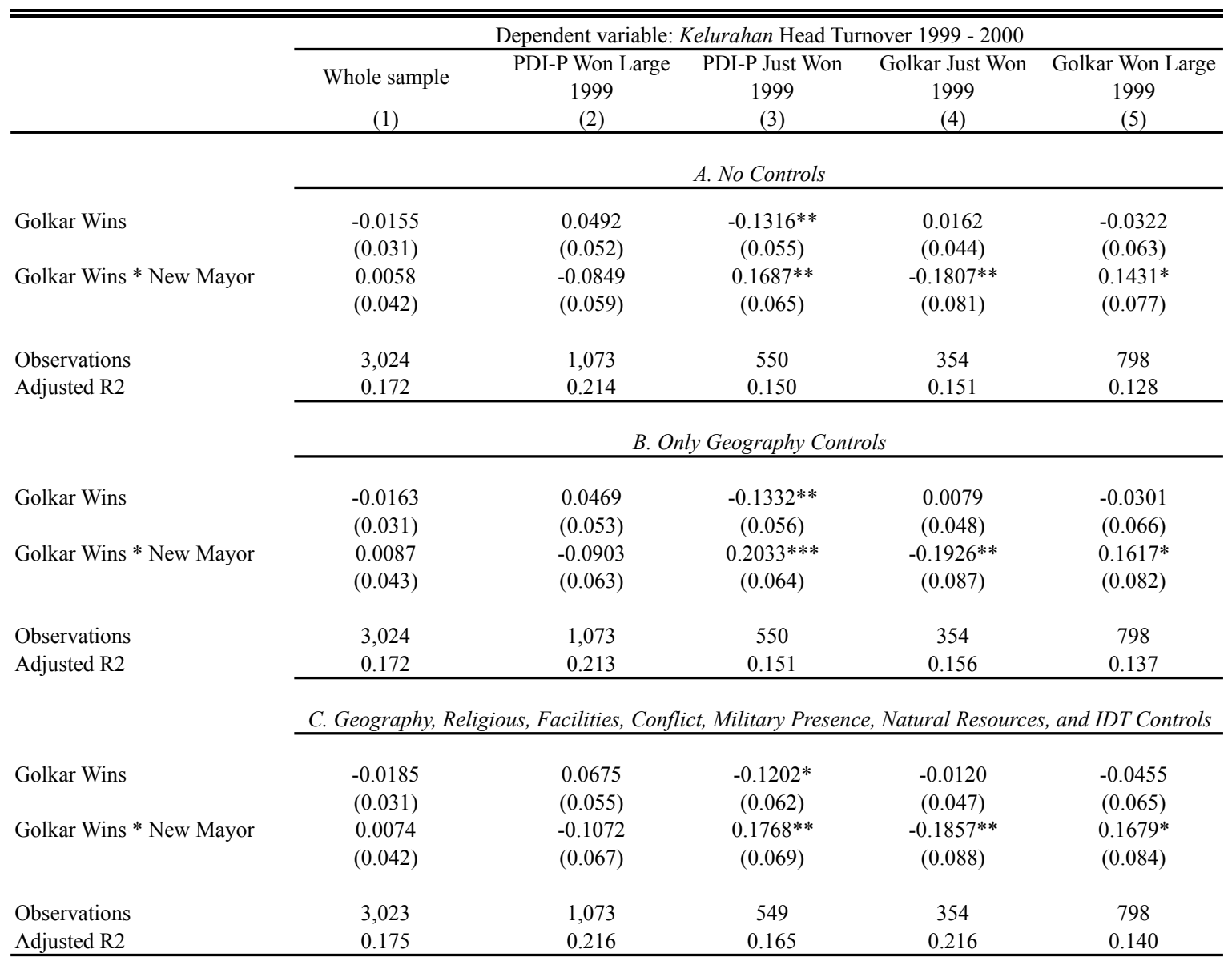

Notes: Robust Standard errors clustered at the district level in parenthesis. The unit of observation is the kelurahan level (villages with an appointed village head). The dependent variable is a dummy that takes value 1 if there was a kelurahan head turnover in the year after the 1999 election. All regressions include district fixed effects. Columns (2) to (5) correspond to the same regression estimated in a different sub-samples. In column (2) the sample is restricted to districts in which PDI-P won by more than 10 percentage points with respect to the second most voted party. In columns (3) the sample is restricted to districts in which PDI-P won by less than 10 percentage points. Similarly for the rest of columns. See the notes of Table 2 for a complete list of geographic, religious, and facilities controls. Panel $\mathrm{C}$ also includes the following set of controls: Incidence of conflict controls are dummies for conflict between villagers and the government apparatus, conflict between students, conflict among villagers and other types of conflict. Presence of the army and the police controls include dummy for whether at least one army member is present in the village, existence of police or Kamling -guard post- station. Natural resources controls include \% of households in the mining sector and dummies for whether the following minerals are quarried: coralstone, sand, lime, sulfur, quartz, and kaolin. Poverty alleviation program controls include a dummy for whether the village was a IDT recepient and the percentage of households that recevied funds. $* * * \mathrm{p}<0.01, * * \mathrm{p}<0.05, * \mathrm{p}<0.1$. 
Table A.12 Turnover Robustness Checks - Different Margins of Victory

\begin{tabular}{|c|c|c|c|c|c|c|c|c|c|}
\hline & \multirow{2}{*}{$\begin{array}{c}\text { Whole Sample } \\
\text { (1) } \\
\end{array}$} & \multicolumn{4}{|c|}{ PDI-P Won } & \multicolumn{4}{|c|}{ Golkar Won } \\
\hline & & $\begin{array}{c}>20 \% \\
(2) \\
\end{array}$ & $\begin{array}{c}10 \%-20 \% \\
(3) \\
\end{array}$ & $\begin{array}{c}5 \%-10 \% \\
(4)\end{array}$ & $\begin{array}{c}<5 \% \\
(5) \\
\end{array}$ & $\begin{array}{c}<5 \% \\
(6) \\
\end{array}$ & $\begin{array}{c}5 \%-10 \% \\
(7)\end{array}$ & $\begin{array}{c}10 \%-20 \% \\
(8)\end{array}$ & $\begin{array}{c}>20 \% \\
\quad(9) \\
\end{array}$ \\
\hline & \multicolumn{9}{|c|}{ A. Dependent variable: Kelurahan Head Turnover $1999-2000$} \\
\hline Golkar Wins & $\begin{array}{l}-0.0152 \\
(0.031)\end{array}$ & $\begin{array}{l}0.0670 \\
(0.074)\end{array}$ & $\begin{array}{l}0.0592 \\
(0.079)\end{array}$ & $\begin{array}{c}-0.1324 \\
(0.117)\end{array}$ & $\begin{array}{l}-0.0909 \\
(0.057)\end{array}$ & $\begin{array}{l}0.1020^{*} \\
(0.054)\end{array}$ & $\begin{array}{c}-0.0278 \\
(0.081)\end{array}$ & $\begin{array}{l}-0.0439 \\
(0.154)\end{array}$ & $\begin{array}{r}-0.0322 \\
(0.082)\end{array}$ \\
\hline Golkar Wins * New Mayor & $\begin{array}{l}0.0057 \\
(0.042)\end{array}$ & $\begin{array}{l}-0.0923 \\
(0.146)\end{array}$ & $\begin{array}{l}-0.0884 \\
(0.087)\end{array}$ & $\begin{array}{l}0.1434 \\
(0.132)\end{array}$ & $\begin{array}{c}0.4128 * * * \\
(0.101)\end{array}$ & $\begin{array}{c}-0.2129 * * \\
(0.089)\end{array}$ & $\begin{array}{c}-0.3120^{*} \\
(0.149)\end{array}$ & $\begin{array}{l}0.2489 \\
(0.186)\end{array}$ & $\begin{array}{l}0.1484 \\
(0.109)\end{array}$ \\
\hline \multirow[t]{2}{*}{ Adjusted R2 } & $\begin{array}{l}3,024 \\
0.175 \\
\end{array}$ & $\begin{array}{c}527 \\
0.145 \\
\end{array}$ & $\begin{array}{c}546 \\
0.295 \\
\end{array}$ & $\begin{array}{c}337 \\
0.193 \\
\end{array}$ & $\begin{array}{c}213 \\
0.130 \\
\end{array}$ & $\begin{array}{c}188 \\
0.174 \\
\end{array}$ & $\begin{array}{c}166 \\
0.0299 \\
\end{array}$ & $\begin{array}{c}111 \\
0.0784 \\
\end{array}$ & $\begin{array}{c}687 \\
0.150 \\
\end{array}$ \\
\hline & \multicolumn{9}{|c|}{ B. Dependent variable: Kelurahan Head Turnover 1995 - 1996 (Placebo Test) } \\
\hline Golkar Wins & $\begin{array}{l}-0.0199 \\
(0.024)\end{array}$ & $\begin{array}{l}0.0546 \\
(0.040)\end{array}$ & $\begin{array}{l}-0.0087 \\
(0.078)\end{array}$ & $\begin{array}{l}-0.0355 \\
(0.133)\end{array}$ & $\begin{array}{l}-0.0956 \\
(0.067)\end{array}$ & $\begin{array}{c}-0.0765^{*} \\
(0.036)\end{array}$ & $\begin{array}{l}-0.0662 \\
(0.107)\end{array}$ & $\begin{array}{l}-0.1351 \\
(0.159)\end{array}$ & $\begin{array}{r}-0.0479 \\
(0.065)\end{array}$ \\
\hline Golkar Wins * New Mayor & $\begin{array}{l}0.0222 \\
(0.037)\end{array}$ & $\begin{array}{c}-0.1178^{*} \\
(0.063)\end{array}$ & $\begin{array}{l}0.0693 \\
(0.106)\end{array}$ & $\begin{array}{l}-0.1277 \\
(0.151)\end{array}$ & $\begin{array}{l}0.1484 \\
(0.090)\end{array}$ & $\begin{array}{l}0.0801 \\
(0.055)\end{array}$ & $\begin{array}{l}0.1076 \\
(0.136)\end{array}$ & $\begin{array}{l}0.0463 \\
(0.086)\end{array}$ & $\begin{array}{c}0.1861^{* *} \\
(0.090)\end{array}$ \\
\hline Observations & 3,024 & 527 & 546 & 337 & 213 & 188 & 166 & 111 & 687 \\
\hline Adjusted R2 & 0.184 & 0.223 & 0.266 & 0.222 & 0.0985 & 0.189 & 0.0463 & 0.279 & 0.0856 \\
\hline
\end{tabular}

Notes: Robust Standard errors clustered at the district level in parenthesis. The unit of observation is the kelurahan level (villages with an appointed village head). The dependent variable in Panel A is a dummy that takes value 1 if there was a kelurahan head turnover in the year after the 1999 election. The dependent variable in Panel B is a dummy that takes value 1 if there was a kelurahan head turnover in the year before 1996. All regressions include district fixed effects, geographic, religious, and facilities controls (see notes in Table 2 for a complete list of these controls). Columns (2) to (9) correspond to the same regression estimated in a different sub-samples. Columns (2) to (5) correspond to districts where PDI-P was the most voted party in the 1999 election. Columns (6) to (9) correspond to districts where Golkwas was the most voted party in the 1999 election. In column (2) the sample is restricted to districts in which PDI-P won by more than 20 percentage points with respect to the second most voted party. In columns (3) the sample is restricted to districts in which PDI-P won by a margin of victory between 10 and 20 percentage points. Similarly for the rest of columns. ${ }^{* * *} \mathrm{p}<0.01,{ }^{* *} \mathrm{p}<0.05,{ }^{*} \mathrm{p}<0.1$. 


\section{Appendix Figures}
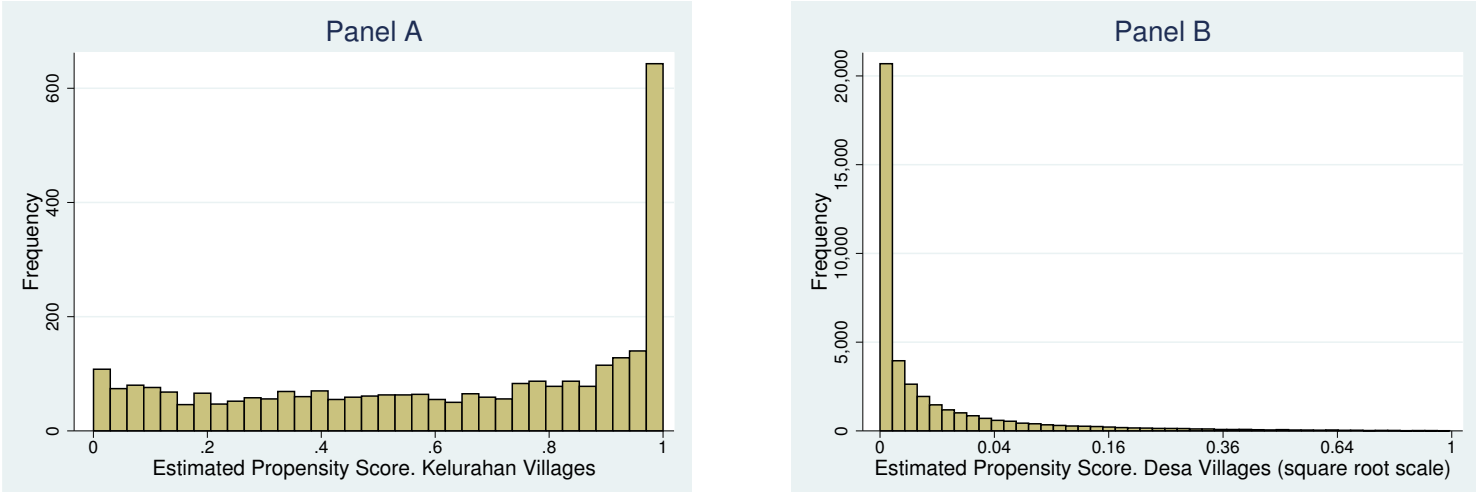

Figure A1. These histograms display the frequency of the the propensity score estimates of kelurahan and desa. The propensity score model includes geographic, religious, and facilities controls, and district fixed effects. Since a large fraction of desa villages have propensity scores near 0, Panel B is represented using a square root scale. 


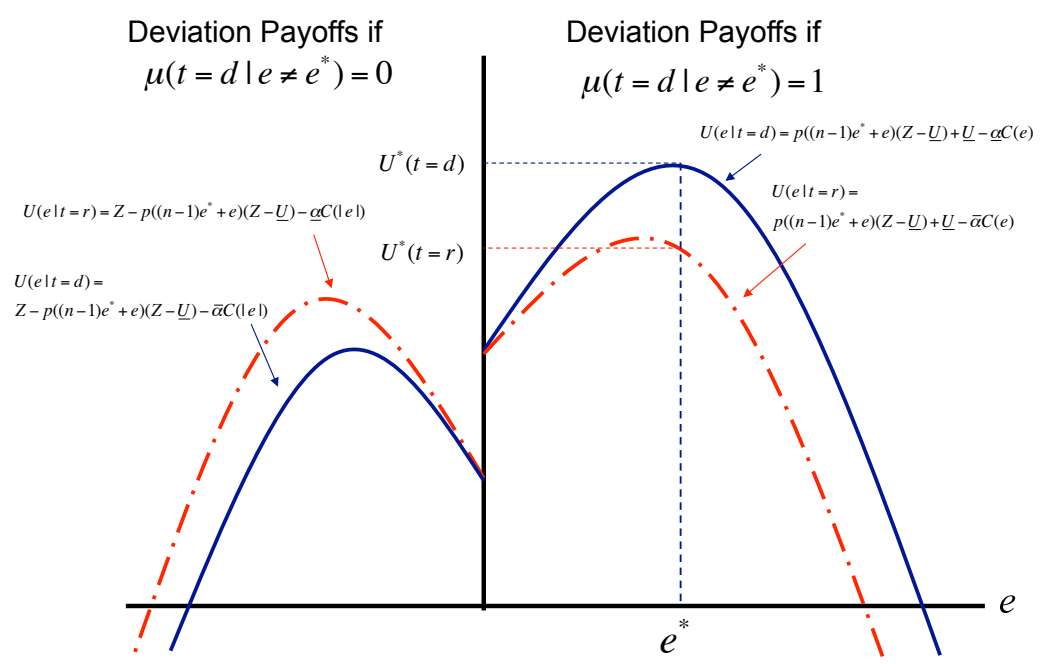

Figure A2. Turnover Differences Across Districts

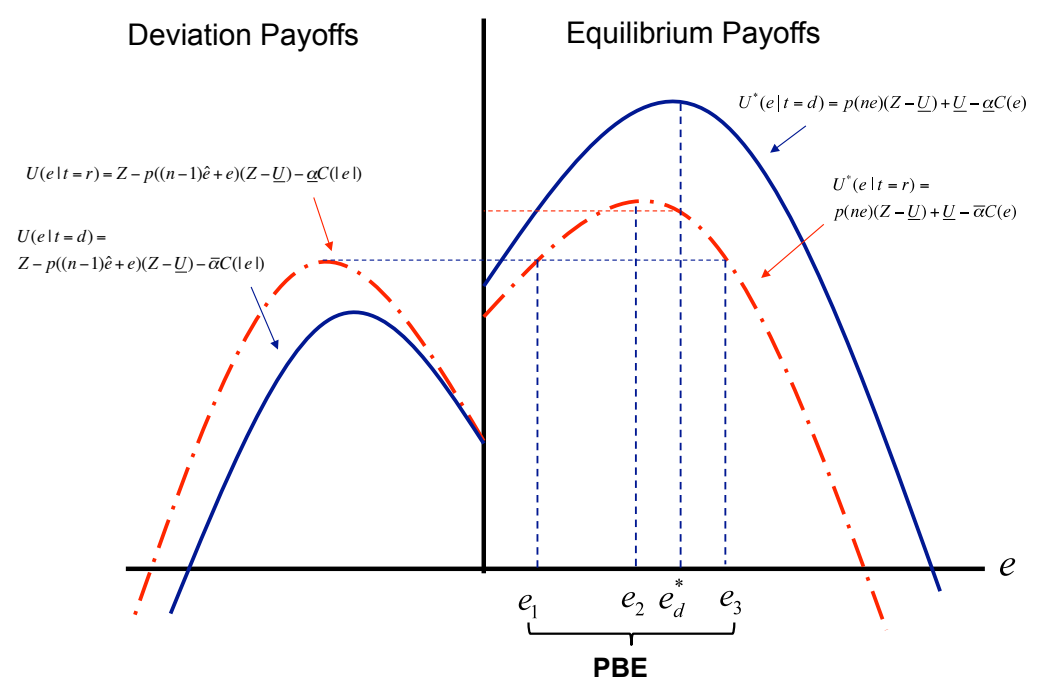

Figure A3. Endogeneity Check 